\title{
Imagen impresa y ciudad, Buenos Aires (1890-1910)
}

\section{ANA BONELLIZAPATA}

anabonelli@gmail.com - Instituto de Altos Estudios Sociales (IDAES), Universidad Nacional de San Martín (UNSAM), Argentina.

Fecha de recepción: 23 de octubre de 2017

Fecha de aceptación: 19 de noviembre de 2017

\section{RESUMEN}

Los últimos años del siglo XIX en Buenos Aires fueron testigos de importantes cambios en el campo de lagráfica, conla introducción de nuevas técnicas, circulación de objetos e imágenes impresas, así como en la percepción y experiencia de la ciudad misma. Las transformaciones del espacio, tanto público como privado, así como sus representaciones, dan cuenta denuevas prácticas de sociabilidad, nuevos significados y la conformación de una nueva cultura visual en torno a la "metrópolis" y el "progreso". El ferrocarril, comomediodetransporteytecnología, perotambién como marca visible en el espacio, jugará también un rol en esos cambios, y su representación irá estrechamente vinculada con ellos.

La imagen impresa, más allá de sus múltiples relaciones con el campo artístico, posee características propias en cuanto a sus modos de producción (máso menos artesanal, más o menos industriales), su materialidad (inserta en diversos soportes, múltiple, con mayor o menor vinculación a un discurso textual), así como las redes de circulación que implica. En este sentido, se propone pensar de cuáles modos particulares las imágenes impresas aparecidas en este contexto se relacionaron con la percepción y la experiencia del espacio, las nuevas tecnologías y el consumo urbano.
PALABRAS CLAVE: Ilustración, siglo XIX, Buenos Aires, cultura impresa, urbanismo.

\section{ABASTRACT}

The last years of the XIX century in Buenos Aires witnessed important changes both in the field of graphics, with the introduction of new techniques, circulation of printed objects and images, as well as in the perception and experience of the city. The transformations of space, both public and private, and their representations, account for new practices of sociability, new meanings and the formation of a new visual culture around the "metropolis" and "progress". The railway, as transportand technology, but also as a visible mark in space, will also play a role in these changes, and its representations will be closely linked with them.

The printed image, beyond its multiple relationships with the artistic field, has its own characteristics in terms of its modes of production (more or less handmade, more or less industrial), its materiality (inserted in various supports, multiple, with greater or lesser link to a textual discourse), and circulation networks involved. In this direction, it is proposed to think in which particular ways the printed images appeared in this context were related to the perception and experience of space, new technologies and urban consumption.

KEYWORDS: Illustration, nineteenth century, Buenos Aires, print culture, urbanization. 


\section{INTRODUCCIÓN}

El drama de la modernidad se delinea a sí mismo: el colapso de las experiencias previas de espacio y tiempo a través de la velocidad.

Tom Gunning (1995, p. 16) 1 .

Los dispositivos gráficos (dispositivos, como objetos "multilineales", individuales, en desequilibrio [Deleuze, 1999, p. 155], que implican regímenes de visibilidad y enunciación específicos, umbrales que abren múltiples relaciones con otros dispositivos, siempre complejos, siempre históricos) se vinculan por diferentes vías a intereses económicos y políticos contemporáneos. Su inserción en el espacio público, en diversos soportes materiales, que involucran prácticas de lectura y observación también diversas ${ }^{2}$, los transforman en objetos sumamente complejos e interesantes a la hora de analizar la cultura visual contemporánea.

Los últimos años del siglo XIX en Buenos Aires fueron testigos de importantes cambios en el campo de la gráfica, con la introducción de nuevas técnicas, circulación de objetos eimágenes impresas, así como en la percepción y experiencia de la ciudad misma. Las transformaciones del espacio, tanto público como privado, así como sus representaciones, dieron cuenta de nuevas prácticas de sociabilidad, nuevos significados y la conformación de una nueva cultura visual en torno a la "metrópolis" y el "progreso". Los avisos publicitarios, particularmente, utilizarán el recurso de las ilustraciones de diferentes maneras, como clichés insertos en las publicaciones, en páginas o secciones especiales. En ellos, comienzan a reiterarse representaciones de las fachadas comerciales o industriales, y de la ciudad como espacio privilegiado de consumo.

Las imágenes aparecen en un campo gráfico en transformación, y van ganando terreno en la prensa, sobre todo en las publicaciones ilustradas, cuya marca de diferenciación radicaba, precisamente, en la posibilidad de vincular el discurso textual con el visual en el mismo soporte, a partir de las nuevas tecnologías de impresión. También lo harán, sin embargo, en publicaciones con fines comerciales, políticos, sociales, en las ilustraciones de noticias, incorporación de diagramas, gráficos, grillas, planos y, particularmente, en las imágenes publicitarias ${ }^{3}$.

1 "In all of these new systems of circulation, the drama of modernity sketches itself: a collapsing of previous experiences of space and time through speed; an extension of the power and productivity of the human body; and a consequent transformation of the body through new thresholds of demand and danger" (Gunning, 1995, p. 16; traducción propia).

2 Pienso, por ejemplo, en imágenes que se reiteran en diarios de actualidad, en revistas ilustradas, en catálogos, en afiches de diversos tamaños; por nombrar sólo algunos de los soportes impresos más comunes en la época.

3 Me refiero aquí a imágenes cuya producción y circulación se vinculan estrechamente con intereses comerciales, ya sea que anuncien un producto o servicio, o exhiban determinados espacios, objetos o figuras asociadas a la producción o consumo de estos productos o servicios (ilustraciones de fábricas, talleres, bazares, almacenes, planos, grillas, etc.), aun cuando el objetivo comercial esté matizado por el contexto de la publicación. En este sentido es interesante el texto de Paula Félix-Didier y Sandra Szir sobre las características delos primeros anuncios ilustrados en la prensa periódica en Buenos Aires (2004). 
Frente a una abrumadora cantidad de avisos o reclames textuales, comienzan a surgir grabados que cortan la monotonía de las secciones de anuncios que se imprimían al principio o al final del volumen. La posibilidad técnica de incluir viñetas o fotograbados en la misma página del texto, modifica a su vez la práctica de ordenar estas secciones al principio o al final del volumen, agrupados por rubro, como los actuales clasificados. Así, los clichés publicitarios comienzan a insertarse también entre los artículos de actualidad o de interés general, suplementos literarios o entrevistas, generando una continuidad o ruptura con el discurso textual, en lo que Peter Sinnema describe como "momento visual-verbal" (1998, p. 2).

Para los grandes autores de la ruptura de la modernidad, como Aby Warburg y Walter Benjamin, la imagen "se convertía en la encrucijada sensible de esta escisión: un síntoma, una crisis detiempo" (Didi-Huberman, 2008, p. 296). A partir del análisis de estas imágenes publicitarias de los últimos años del siglo XIX (aun cuando su carácter simbólico fuera prácticamente marginado en pos de una aparente objetividad) podemos encontrar estas crisis, estos detalles sintomáticos. Por ejemplo los clichés creados para periódicos británicos que fueron utilizados, años después, por las imprentas porteñas, en contextos diferentes, rodeados de otros discursos, remiten a condiciones técnicas, modos de producción y circulación de los objetos, pero también a la vinculación entre ambos países, y la dinámica política y económica que, aún en los momentos más álgidos de la crisis financiera por la que atravesóla Argentina, conectó a empresarios, trabajadores, artistas, productores y consumidores, de distintos puntos del planeta.

Figura 1: Aviso de Pozos Artesianos. The Financial Review of the River Plate, $\mathrm{n}^{\circ} 2,19$ de diciembre de 1891.

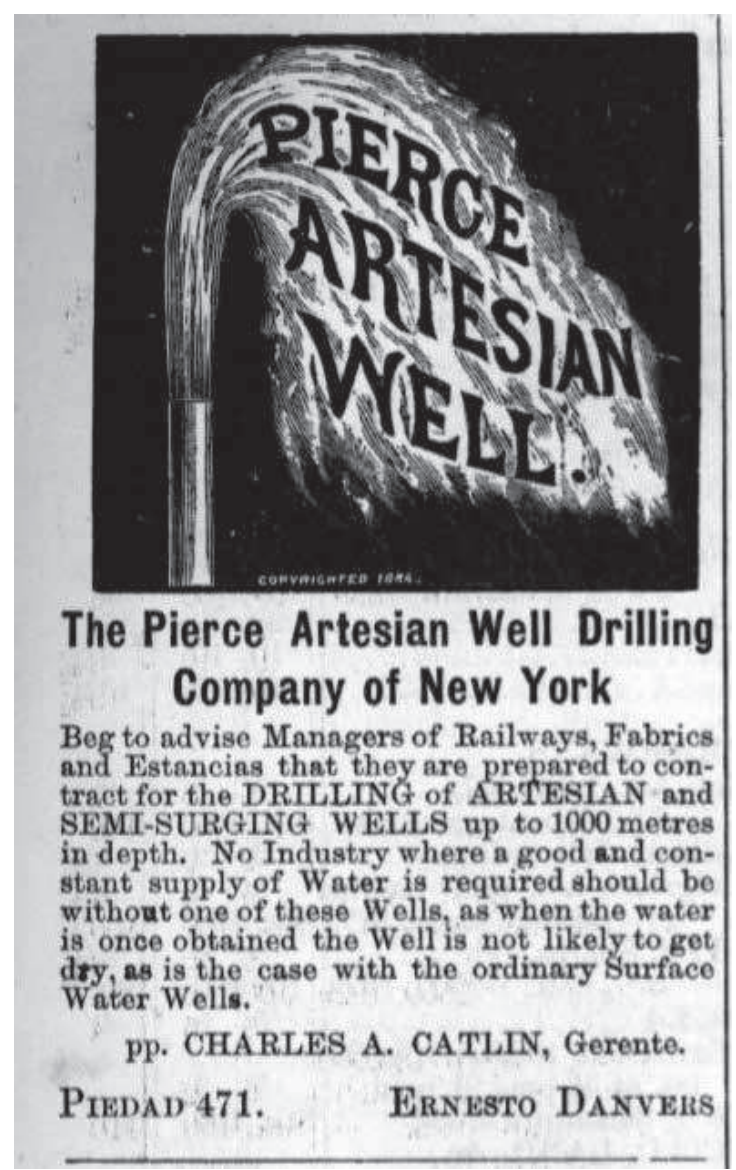


Esta imagen como síntoma, propia de la experiencia de la modernidad, se complejiza en su relación con el texto. Relación no armónica, sino que, en palabras de Sinnema (1998), sería un ensamble de contradicciones. Contradicción en el mismo discurso escrito, tensiones en la imagen, en los tiempos y experiencias que se cruzan, en la percepción que intenta ordenar ambos discursos.

Estas tensiones introducen a los lectores en una zona gris, que, más allá de la crisis, produce una situación de enorme potencial creativo y significativo. El "momento visual-verbal" para Sinnema, similar a la "ocasión" para De Certeau (1990), es la forma en que la imagen y el texto se presentan ante un observador experimentado en lo efímero, en lo transitorio, en los accidentes y el azar. Un observador (más que espectador o lector, como vimos) que es capaz de confrontar ambos discursos de forma creativa y que es capaz de reconfigurar esa misma experiencia.

En este artículo nos proponemos centrar la atención sobre un corpus particular de imágenes que aparecen reproducidas en las publicaciones periódicas que circularon durante la última década del siglo XIX, en Buenos Aires. En una gran cantidad de estos primeros reclames aparece el espacio urbano, particularmente los grandes edificios de la metrópolis porteña, como sujeto de enunciación, apelando a un observador que experimenta las transformaciones impulsadas por la elite gobernante en una ciudad aún en construcción.

Nosinteresan en especial aquellas imágenes producidas en y para contextos no artísticos, incluso en periódicos considerados "no ilustrados" en un sentido restringido (Szir, 2009, p. 58), precisamente, por la sutileza y complejidad con que estas tensiones se despliegan, vinculándose estrechamente con disciplinas y campos aparentemente diferenciados.

La modernidad, además de los cambios en la experiencia subjetiva, también amplió el universo delo visible, de aquello que merecía ser visto, apreciado. Existió una "apertura del campo de los objetos (...). La imaginación desborda por todos lados los límites del arte", rescata Didi-Huberman (2008, p. 147). La proliferación de publicaciones ilustradas, afiches, boletines, catálogos, postales, entre otras, es posible también gracias a esta apertura, en gran parte técnica. Es necesario "incorporar la tecnología como otra variable de análisis, que explica no sólo los efectos que produce sobre la imagen en sí y en las prácticas de la lectura, sino también la notable expansión de imágenes reproducidas en revistas y otros soportes como el afiche publicitario o las postales" (Malosetti Costa \& Gené, 2009, p. 13).

Uno de los objetivos principales del trabajo será, por lo tanto, comprender el rol de estos dispositivos en la conformación de la cultura visual, así como en la construcción de un imaginario urbano de la ciudad de Buenos Aires en el cambio de siglo. 


\section{ARQUITECTURAS MODERNAS, CONSUMO E IDENTIDAD}

La ciudad de Buenos Aires fue testigo de una transformación sin precedentes en las últimas décadas del siglo XIX. La federalización de la ciudad en 1880 marcó una bisagra en su historia, pero se comprende únicamente en el marco de los proyectos políticos y económicos en pugna desde las mismas guerras de independencia en la primera mitad dela centuria. Su crecimiento demográfico, a raíz de una balanza económica favorable por las inversiones extranjeras en sectores claves como los ferrocarriles, estuvo acompañado de cambios urbanísticos que no siempre alcanzaron a cubrir las necesidades de una población cada vez mayor y más compleja (Scobie, 1974; Bourdé, 1977; Bonaudo, 1999; Liernur, 2000; Lobato, 2000).

Surgirá lentamente una ciudad que compartirá en el mismo terreno funciones comerciales, administrativas y culturales, vinculadas con el modelo agroexportador. En este sentido, el ferrocarril, el puerto, los palacios de la oligarquía bonaerense, así como edificios especialmente diseñados para depósitos, almacenes o tiendas, marcaron el entramado urbano de casas bajas. Las lentas mejoras en la higiene y la iluminación, más el planeamiento de la ciudad recién se percibirán en su esplendor en las primeras décadas del siglo $\mathrm{XX}$, con la difusión de la electricidad, el asfalto y los modernos transportes, entre otros elementos. Estos cambios y el vértigo no pasaban desapercibidos para los contemporáneos:

\footnotetext{
Buenos Aires: “¡Una ciudad muy fea bajo un hermosísimo cielo!”: esta fue la impresión que me formé de Buenos Aires cuando desembarqué por primera vez allí, en el año de 1879. El cielo es el mismo ahora que entonces, pero cómo se ha transformado la ciudad! [sic] No es exageración decir que ha sido completamente reedificada en los últimos veinte años y que esta reedificación se ha llevado á cabo con gusto y elegancia. Con excepción de la Catedral, no reconocí ningún edificio como siendo del tiempo de mi residencia anterior (Samson, 1904, p. 6).
}

Este crecimiento urbano de Buenos Aires se caracterizará como "comercial burocrático" (Scobie, 1974, p. 250) o una "urbanización sin industrialización” (Bourdé, 1977, p.9) quela diferenciará de las principales ciudades europeas. La definición de un proyecto político liberal y un modelo económico ligado a los intereses de los grandes terratenientes retrasará en gran medida el desarrollo de una industria pesada, fomentandolas actividades y establecimientos de manufacturas de bienes primarios (saladeros, curtiembres, aserraderos, molinos) que se instalarán por diversos motivos en los suburbios, marcando de diferente manera el territorio, así como las prácticas y representaciones ligadas a él.

La representación de esos cambios urbanos en la prensa se vinculará a su vez con los cambios técnicos de la propia actividad gráfica, que verá una mayor tecnificación y complejidad tanto en la producción como en la circulación de 
los objetos impresos y los modelos, máquinas, clichés y profesionales, a nivel local e internacional. Entre 1892 y 1893 se imprimió en la ciudad de Rosario el álbum Estadística Gráfica. Progreso de la República Argentina en la Exposición de Chicago 4 . Las láminas litográficas, realizadas por diferentes artistas, algunas anónimas, representaban las fachadas olosinteriores de talleres, bazares, fábricas y espacios turísticos, como las Termas de Rosario de la Frontera, en Salta. Involucraban, asimismo, una variedad de estilos y códigos visuales referidos al paisaje y la representación arquitectónica, así como modos heterogéneos de composición de la imagen, alejándose en menor o mayor medida de las vistas tradicionales en la gráfica contemporánea y condicionando un mayor uso publicitario de los objetos.

Simultáneamente, en diversas publicaciones impresas vinculadas alámbito económico o comercial (tales como The Standard, The Review of the River Plate, la Revista Mercantil), o literarios y de novedades (El Sud-Americano, el Álbum Ilustrado, por ejemplo), surgieron y tomaron mayor protagonismo las publicidades ilustradas ${ }^{\mathbf{5}}$. En estas imágenes aparecían representadas con frecuencia las fachadas, especialmente las esquinas de las grandes tiendas. Se trataba de vistas majestuosas que, en general, implicaban una espacialidad urbana artificial, considerando la ubicación de esos mismos edificios en las calles céntricas y, en ese entonces, angostas de Buenos Aires.

Esta construcción de una imagen urbana en torno al consumo involucraba una experiencia concreta de los ilustradores, así como de los lectores de los periódicos o revistas. A su vez, remitía a prácticas de sociabilidad y experiencias perceptivas características de la modernidad: "la percepción, dentro del contexto de la modernidad, nunca revelaba el mundo como presencia. El observador puede identificarse [en los textos de Benjamin], por ejemplo, con un flanéur, "un consumidor móvil de una incesante sucesión de imágenes ilusorias como mercancías" (Crary, 2008, p. 46).

En este sentido, las imágenes son a su vez testigos y formadoras de estas percepciones, al insertarse en un conjunto de prácticas que incluían, a un mismo nivel, el paseo por la ciudad y las grandes tiendas y el paseo visual por las publicaciones impresas. Los observadores participaban de ambos recorridos, y las expectativas puestas en juego dependían tanto de esas experiencias físicas como de las representaciones. No es sólola materialidad, sino también las prácticas y las experiencias de los habitantes las que configuran un determinado espacio urbano ${ }^{6}$.

4 Para más información sobre este álbum, léase el artículo de Ana Bonelli Zapata (2016).

5 Un interesante antecedente, interesante por su carácter excepcional, son los reclames aparecidos desde fines de la década de 1860 en El Mosquito, ilustrados por el mismo Henry Stein. Véase a Claudia Román (2017).

6 Mirta Lobato, en su estudio del espacio fabril de la localidad de Berisso, lo describe como "conformado no sólo por su materialidad (viviendas, comercios, calles, medios de transporte) sino también por las experiencias vividas en ella y por las formas de pensar y actuar de sus habitantes" (2001, p. 50). 
Figura 2. “Las fiestas de Navidad”. Caras y Caretas, n 65, 30 de diciembre de 1899 (detalle).

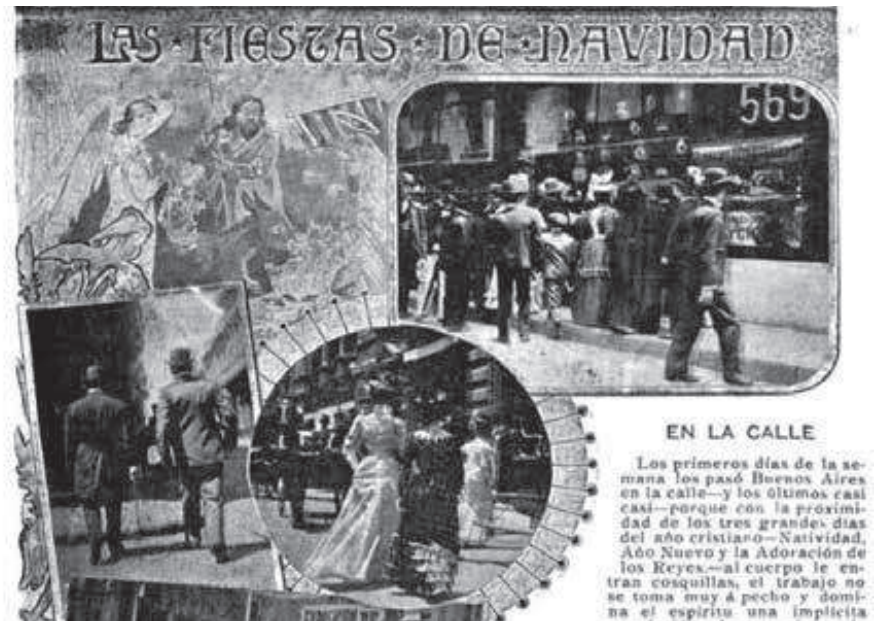

La imagen urbana es una representación mental del medio (Silva, 2006), pero a su vez las imágenes visuales construyen esa representación mental y, en definitiva, dan forma al medio concreto. Es así como los anuncios ilustrados participan de un conjunto de imágenes (visuales y mentales) que apuntan a construir una identidad urbana, una espacialidad y un modo de apropiarse de ese espacio, entre público y privado, de la ciudad moderna, desde la práctica misma del consumo (Gorelik, 1998; Rocchi, 1998).

Encontramos así, a principios de la década de 1890, anuncios ilustrados con estos motivos en el periódico The Standard, de los hermanos irlandeses Michael George y Edward Thomas Mulhall. A partir de la segunda mitad de 1891 se introducen clichés de mayor tamaño y mejor factura, particularmente los de la tienda de ropa Taylor de J. Brown, en Piedad 513, que, de pequeños anuncios promocionando pantalones de montar, pasa a representar la fachada de la tienda, en una perspectiva alta enfatizando la arquitectura y los carteles a la calle (cliché que a su vez será manipulado sucesivamente).

Figura 3: Avisos de Tienda Taylor de J.B. The Standard, 15 de julio de1891; 15 de octubre de 1891; 8 de diciembre de 1891
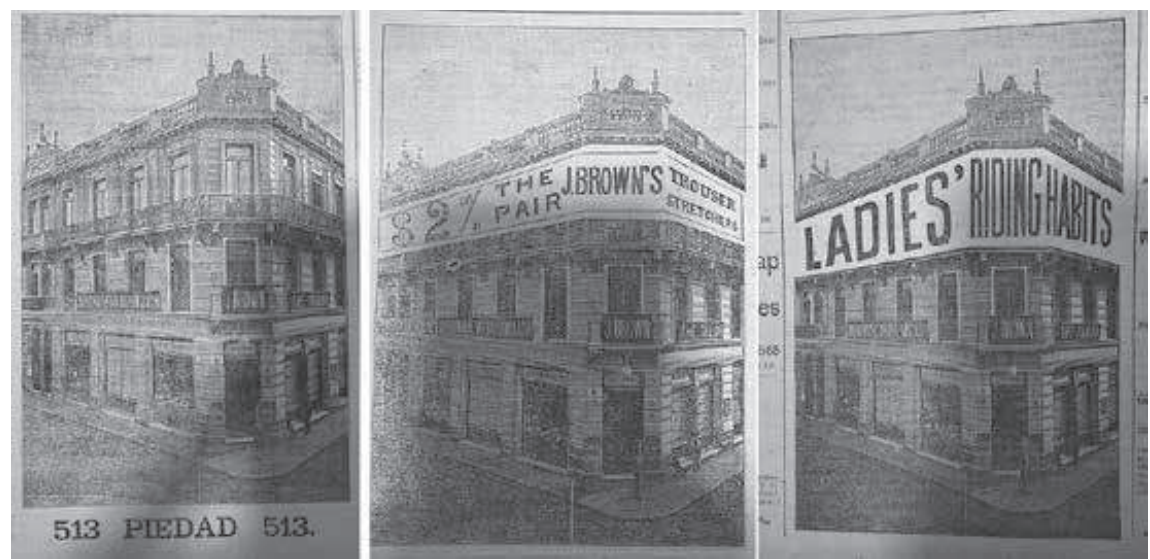
Otros anuncios del mismo tenor, en el mismo periódico, eran los de la tienda A la ciudad de Londres, que si bien incluían una mayor cantidad de textos que la tienda Taylor, presentaban igualmente la fachada, con un doble punto de fuga que remarcaba las dimensiones del edificio (una característica de esta tienda eran sus entradas en las tres calles, Avenida de Mayo, Perú y Victoria). Las diminutas figuras humanas que aparecían reforzaban la monumentalidad, a la vez que ubicaban a la tienda en una de las esquinas más transitadas del centro porteño.

Figura 4: Avisos de Tienda Á la Ciudad de Londres. The Standard, 30 de septiembre de 1891; 11 de diciembre de 1891.
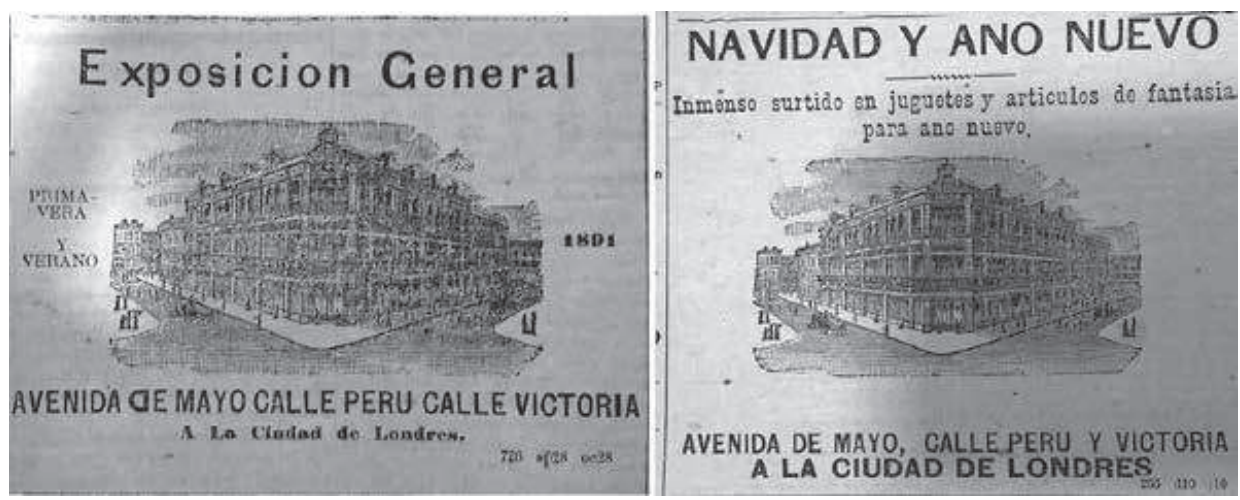

En este sentido, es interesante observar que, de clichés reutilizados, muchos de los cuales llegaban de otros países o talleres y se adecuaban a las necesidades de la edición, se fue pasando paulatinamente a ilustraciones hechas exprofeso para el anuncio, basadas en dibujos

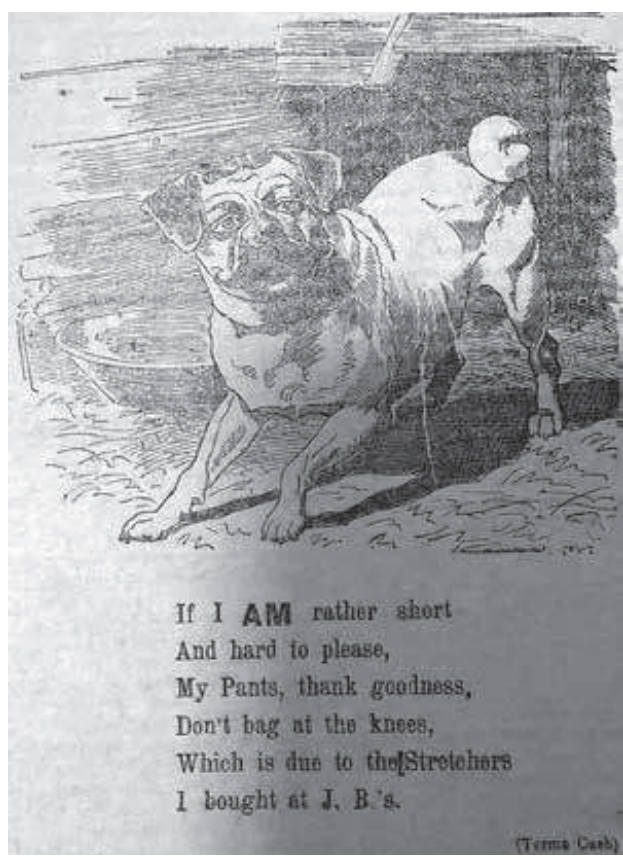
previos, representando el edificio concreto de la tienda. De esta forma surgieron nuevos actores en la trama, como dibujantes, fotógrafos y grabadores, así como prácticas de encargos y una conceptualización de la propaganda más moderna. Estos anuncios, sin embargo, convivían con otros cuyo elemento principal era la tipografía, incluso algunos replicaban ilustraciones con poca relación con el producto del reclame. 
Como dijimos al principio, la imagen urbana es una construcción donde intervienen factores culturales, económicos, políticos, y donde la visualidad juega un rol fundamental, junto con la propia experiencia del observador. En el contexto histórico particular en que circulaban las imágenes, la construcción de la visualidad urbana iba en paralelo con el de una identidad nacional, organizada desde la metrópolis y en clara vinculación a un modelo europeo, diferenciado de otros modelos posibles latinoamericanos. Las imágenes de los grandes edificios comerciales o industriales sostenían esa identidad en términos de progreso, novedad, moda, ciencia y tecnología, entre otros. En este sentido, Víctor Goldgel establece un vínculo entre las vidrieras y los productos que aparecen ilustrados en los periódicos americanos del siglo XIX y el contexto económico y cultural de la revolución industrial: "Durante la época, consumo y maravilla parecen ir de la mano, en la medida en que la revolución industrial y el libre comercio hacen posible que cantidades inusitadas de personas entren en contacto con lo nuevo" (2013, p. 115).

Para la sociedad porteña de fin del siglo XIX, la construcción de una ciudad moderna, con grandes edificios que sirvieran para fines comerciales, industriales, culturales y políticos (tiendas, almacenes, talleres, teatros, museos, monumentos o ministerios, por ejemplo), iba en paralelo con la representación del cosmopolitismo en las redes internacionales. El álbum citado al comienzo, la Estadística Gráfica. Progreso de la República Argentina en la Exposición de Chicago, es un claro ejemplo de esta necesidad de mostrar un progreso no sólo en cuanto a números, sino, y particularmente, en cuanto a la imagen de un país pujante y competitivo. La realización de esteálbum para la Exposición Internacional de Chicago, en la cual Argentina no participaba con un pabellón propio; pero, entre otros objetos, presentaba el óleo de Ángel Della Valle La vuelta del malón, abre la pregunta de cuál o cuáles eran los modos de ver y de reproducir el espacio nacional, ya que la profusión de establecimientos "industriales" remitiría a un control del territorio por parte del gobierno nacional, mientras el cuadro de Della Valle justificaría visualmente la campaña llevada a cabo apenas trece años antes en ese mismo territorio (Malosetti Costa, s/f). 
Figura 6. Bovio, Molino Nuevo Modelo de José Giovanelli \& Cía., Paraná, Entre Ríos. Estadística Gráfica. Progreso de la República Argentina en la Exposición de Chicago, Empresa de la Patria Ilustrada, 1892 (detalle).

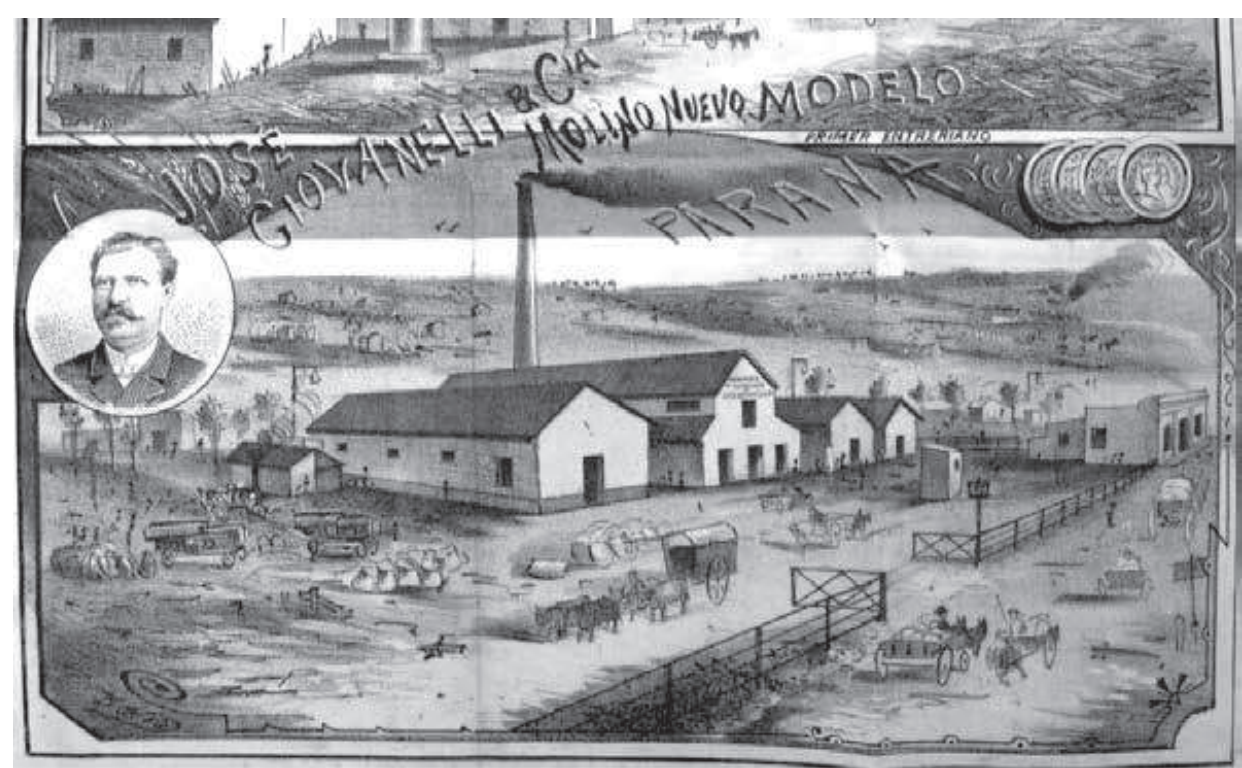

Otro álbum similar publicado unos años antes por la casa de Müller \& Johnson (1891) incluía en su portada un programa repleto de símbolos que reforzaban estosobjetivos. Allínos encontramos con un portal arquitectónico, donde seve un gran arco de medio punto por el que se asoma una pareja. Mercurio, dios mensajero y protector del comercio, acompaña a una mujer que lo abraza. Ambos pasan por delante de la arcada, desde donde se puede observar, a lo lejos, un

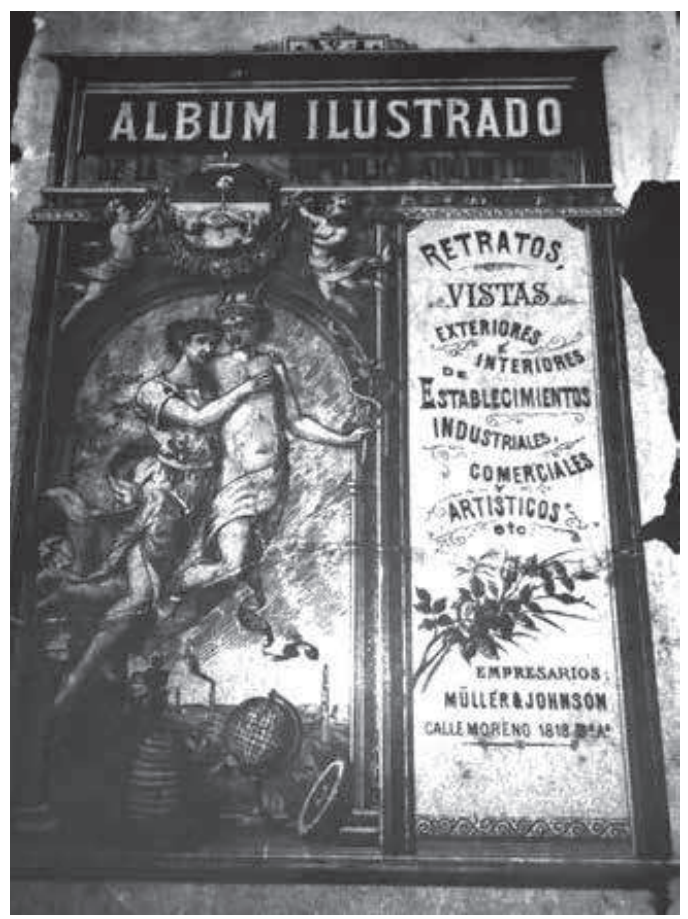
paisaje de chimeneas humeantes. En primer plano se distinguen un globo terráqueo, una rueda de engranaje y otras herramientas de medición y trabajo. Aparecen así los emblemas del comercio, la industria, el progreso, y, coronando la escena, dos querubines adornando con una guirnalda el escudo de la República Argentina. Un gran cartel nos anuncia el contenido del Álbum: "retratos, vistas exteriores e interiores de establecimientos industriales, comerciales y artísticos, etc.".

Figura 7. Portada del Álbum Ilustrado de la República Argentina, n 1 , Editores Müller \& Johnson, 1891 
En este caso, al igual que en el álbum publicado en ocasión de la Exposición de Chicago, no podemos dejar de advertir la intención de propaganda comercial y política de las imágenes. Por un lado, son determinados establecimientos o personajes que merecen la atención de los editores (y de los suscriptores), son los “edificios é instituciones más notables, y la representación de los establecimientos industriales que contribuyen al desarrollo y engrandecimiento del país" los que se ilustran en los diferentes números. El editorial continúa:

\begin{abstract}
Daremos á conocer con grabados artísticos y descripciones sobrias ceñidas á la verdad los establecimientos industriales, y en general los edificios nacionales y particulares, talleres y obras de arte, monumentos ó construcciones de utilidad social que sean dignos de observarse, marcando otro tantos adelantos del país ó incorporación de elementos y factores del desenvolvimiento económico. (...) La vitalidad de un país y sus íntimas energías se traducen casi por completo en aumento de obras, y creación o adquisición de elementos que concurran al progreso material (Álbum Ilustrado de la República Argentina, 15 de julio de 1891).
\end{abstract}

En el interior, se suceden las ilustraciones de los establecimientos, desde la Bolsa de Comercio hasta la casa del empresario Ernesto Tornquist. La ilustración comprende la página entera, mientras que en la página siguiente se encuentra la descripción. Esto respondía tanto a cuestiones de posibilidad técnica de reproducción de las imágenes como a la intención de presentar la ilustración al mismo nivel que el texto.

Las imágenes representan las fachadas, sin respetar las proporciones de las figuras humanas ni los detalles, pero observando un gran cuidado en las líneas arquitectónicas y las fugas, como si se tratara de diseños técnicos más que artísticos. Esta visualidad más descriptiva que narrativa, en la que resaltan pequeñas escenas anecdóticas y una intención de objetividad en la representación del edificio, acerca las imágenes a las pinturas costumbristas de mediados del siglo XIX, a la obra de los artistas viajeros y los dibujantes de las expediciones científicas ${ }^{7}$. Se trata más de una presentación prolija del progreso material proclamado en la editorial, que una imagen ligada a objetivos estéticos o incluso decorativos.

7 Roberto Amigo (2013) desarrolla el costumbrismo en el Río de la Plata, como un primer momento de modernización y a partir de su relación con las luchas facciosas de los gobiernos posrevolucionarios, complejizando la definición del estilo como simple "representación de escenas menores, anecdóticas, de costumbres campesinas o urbanas cosmopolitas” (2013, p. 1). Ver también Majluf, 2006. 


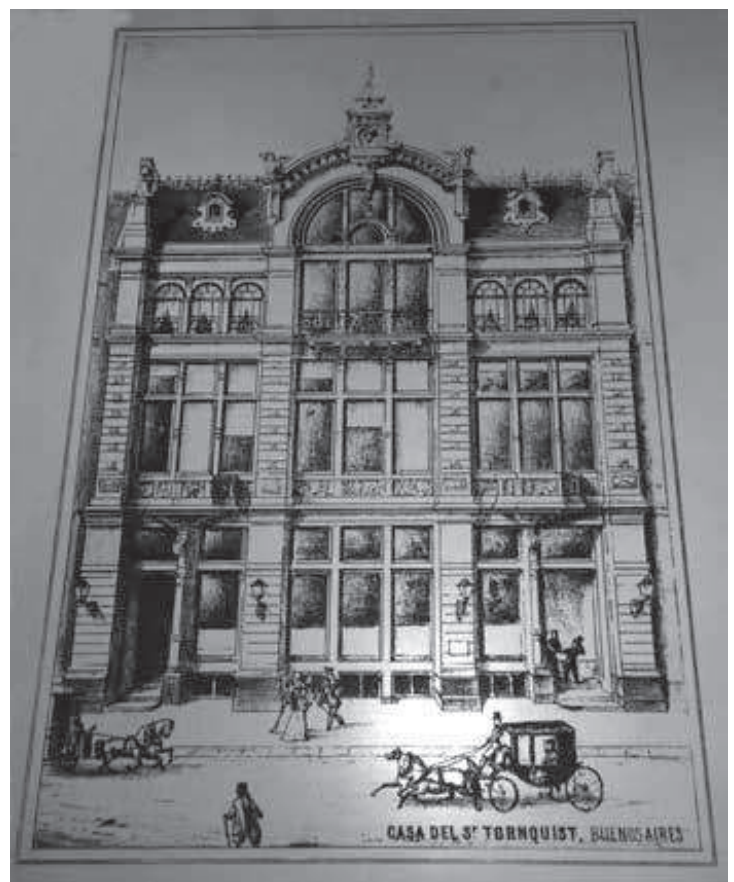

Figura 8. Anónimo. Casa del Sr.

Tornquist, Buenos Aires. Álbum Ilustrado de la República Argentina, $n^{\circ} 1$, Editores Müller \& Johnson, 1891

En cuanto al espacio urbano, al igual que en los ejemplos antes citados, las calles son anchas, luminosas y prolijas. Las pocas figuras humanas se resuelven con gestos rápidos, estableciendo pequeñas escenas callejeras (el caballero que saluda galantemente a las damas, el carruaje y el tranvía a caballo que no se apartan de sus caminos, la pareja que conversa en la esquina) que rompen con la monotonía y la rigurosidad técnica de la arquitectura. Las sombras, mínimas, refuerzan la idea de un espacio abierto, soleado, limpio.

Cuando vemos algunas fotos tomadas durante esos años en las calles del centro porteño nos encontramos, sin embargo, con una escena diferente: calles abigarradas, angostas, por las que pasan, mezclándose, caballos, máquinas y personas. Los toldos, carteles, faroles y cables cruzan el espacio aéreo, que es flanqueado por algunas pocas construcciones de más de dos pisos de altura, pero la mayoría de una sola planta. A lo lejos, tal vez, la silueta de una iglesia o la estación de ferrocarril.

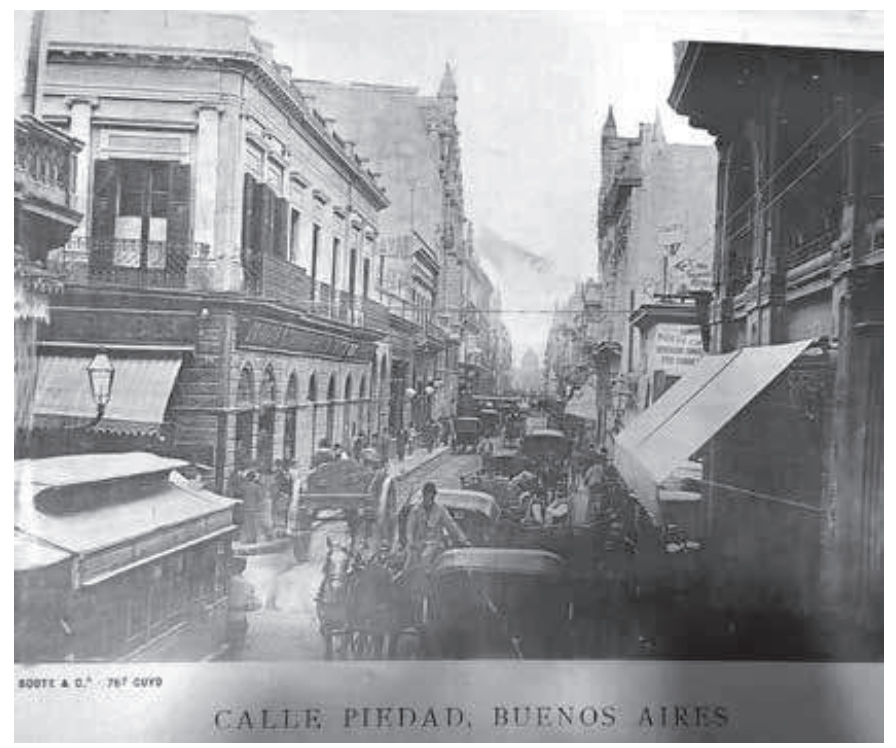

Figura 9. Boote \& Cía., Calle Piedad, Buenos Aires. The Arrow, The monthly illustrated magazine of the River Plate, 1893 
Las grandes tiendas ocupaban espacios emblemáticos. De forma paulatina el centro de Buenos Aires se iba transformando en un espacio comercial, de oficinas, de paseo diario. Las familias con mejores oportunidades instalaban sus casas en los barrios del norte, alejándose de los focos de epidemias que habían asolado décadas antes una ciudad que recién con el cambio de siglo y el centenario mostraría señales más claras de modernidad en cuanto a higiene y planeamiento urbano.

En esta dirección, es interesante la ordenanza municipal que se sanciona en abril de 1904 (y se publica en la Revista Técnica, de la Sociedad Central de Arquitectos), más de diez años después de estos primeros ejemplos, limitando yorganizando tanto la construcción como el desarrollo visual delas fachadas de los edificios que selevantaran, desde ese momento, en las avenidas dela ciudad. En su fundamentación, el concejal Aguirre ${ }^{8}$ manifiesta:

Si se quiere que con el tiempo las avenidas presenten el aspecto estético de la de Mayo o el de las grandes avenidas de París, Berlín, etc., es preciso establecer más adelantelímites de altura y, por ahora, no permitir que selevanten edificios que no respondan a la altura reglamentaria.

La ubicación de las grandes tiendas en las esquinas de las avenidas y calles centrales de Buenos Aires, como la Avenida de Mayo, Piedad (hoy Bartolomé Mitre), Perú, entre otras, respondía a una temprana planificación que, si bien sin la formalización legal, buscaba dotar a la ciudad de una similitud con las grandes capitales europeas a partir de cierta racionalidad estética, y, sobre todo, un discurso modernista que vinculaba los edificios con el entorno urbano.

Los grandes hoteles seguían un desarrollo similar, ubicándose en las esquinas, con amplios locales en la planta baja e importantes cúpulas con miradores, relojes o esculturas que remataban el edificio sobre la entrada principal. En la publicidad de la Compañía Nacional de Grandes Hoteles puede observarse precisamente las mismas características: énfasis en la arquitectura y, particularmente, en la esquina, con doble punto de fuga; desproporción en relación a las figuras humanas, carruajes y otros elementos; aislamiento del edificio en cuanto al entorno urbano, con la disposición de calles anchas; punto de vista alto, que permite la construcción dela vista frontal del edificio (vista totalmente artificial para un transeúnte).

8 Se trata del ingeniero Eduardo Aguirre (1857-1923), quien se destacó por su interés en el conocimiento geológico del territorio argentino, siendo Presidente de la Sociedad Científica Argentina en 1891, Concejal en la ciudad de Buenos Aires entre 1903 y 1907, y Secretario de Obras Públicas en la misma ciudad en diferentes períodos (Camacho, s/f). 
Figura 10. Gran Hotel Internacional. Historia del Ferrocarril Sud, escrita por William Rogind en 1937

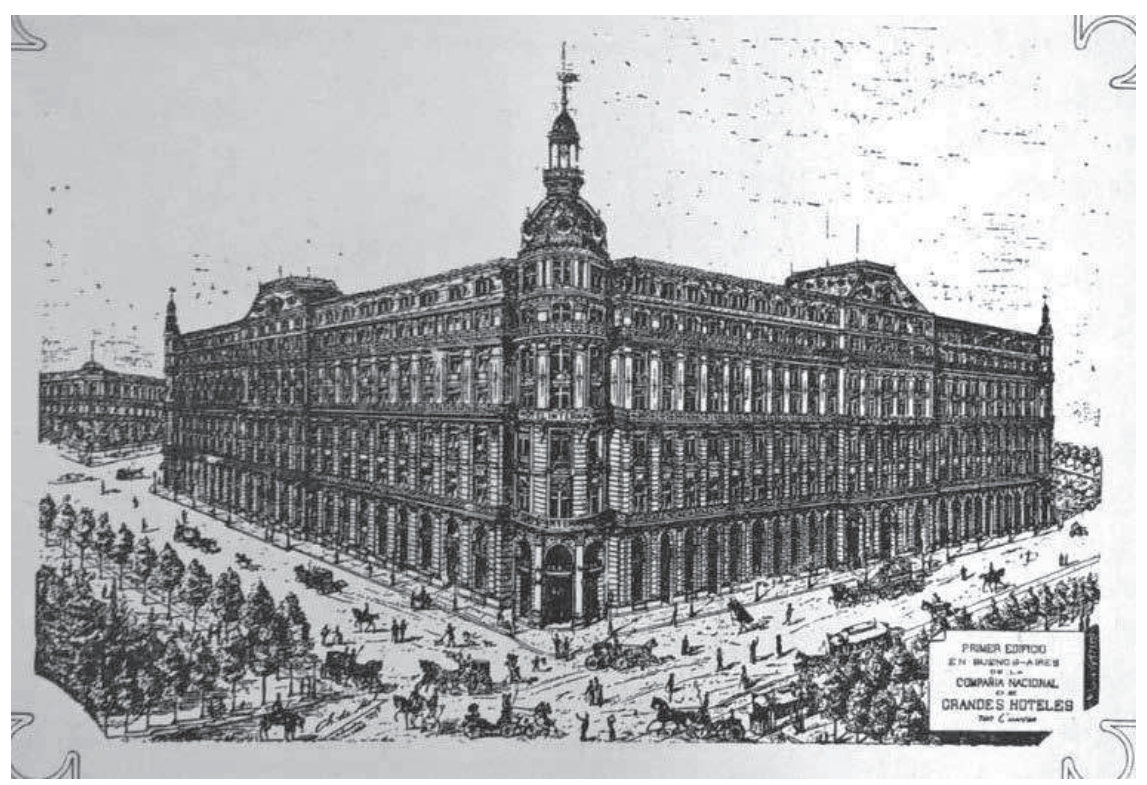

Es interesante este ejemplo precisamente porque los nombres de los fundadores de la Compañía, constituida en 1888, remiten precisamente a esa elite cuyos intereses económicos y políticos transformarían la ciudad porteña: Carlos Pellegrini, Francisco Seeber, Vicente Casares, Eduardo Casey, Francisco Uriburu, Saturnino Unzué, entre otros. Más adelante Ernesto Tornquist se haría cargo de la Compañía y adquirió, entre otros, el Hotel Bristol de Mar del Plata y se inició en el rubro hotelero (Gilbert, 2013).

Estos hoteles de lujo, además de impulsar importantes negocios inmobiliarios, "entran en las grandes ciudades como elementos especializados ligados a la movilidad, que precede al intercambio, o sea [,] como partes integrantes de la ciudad entendida como medio de producción” (Bruno, 2012, p. 54). La arquitectura, y su representación forman parte insoslayable de esa ciudad productora, moderna, "europea".

\section{EL DIBUJO COMO APROPIACIÓN DEL TERRITORIO}

Jonathan Crary (2008) observa que el régimen visual de la modernidad depende, antes que de una invención particular como la fotografía, "de una nueva ordenación del conocimiento del cuerpo y la relación constitutiva de ese conocimiento con el poder social" (p.36), por lo que es posible reconocerlo en objetos no fotográficos, anteriores o contemporáneos. La utilización de un dibujo prolijo, técnico, privilegiando la arquitectura como un elemento estable, inmutable, monumental frente a la transitoriedad de las personas y con un punto de vista construido, implicaba una pretensión de objetividad compartida con las ilustraciones técnicas como diagramas, mapas y planos. 
Figura 11. Nuevas instalaciones de la Estación del Once de Septiembre. El Ingeniero Civil, Editor Guillermo Kraft, Año 1, n 3, 1 de mayo de 1888 (detalle).

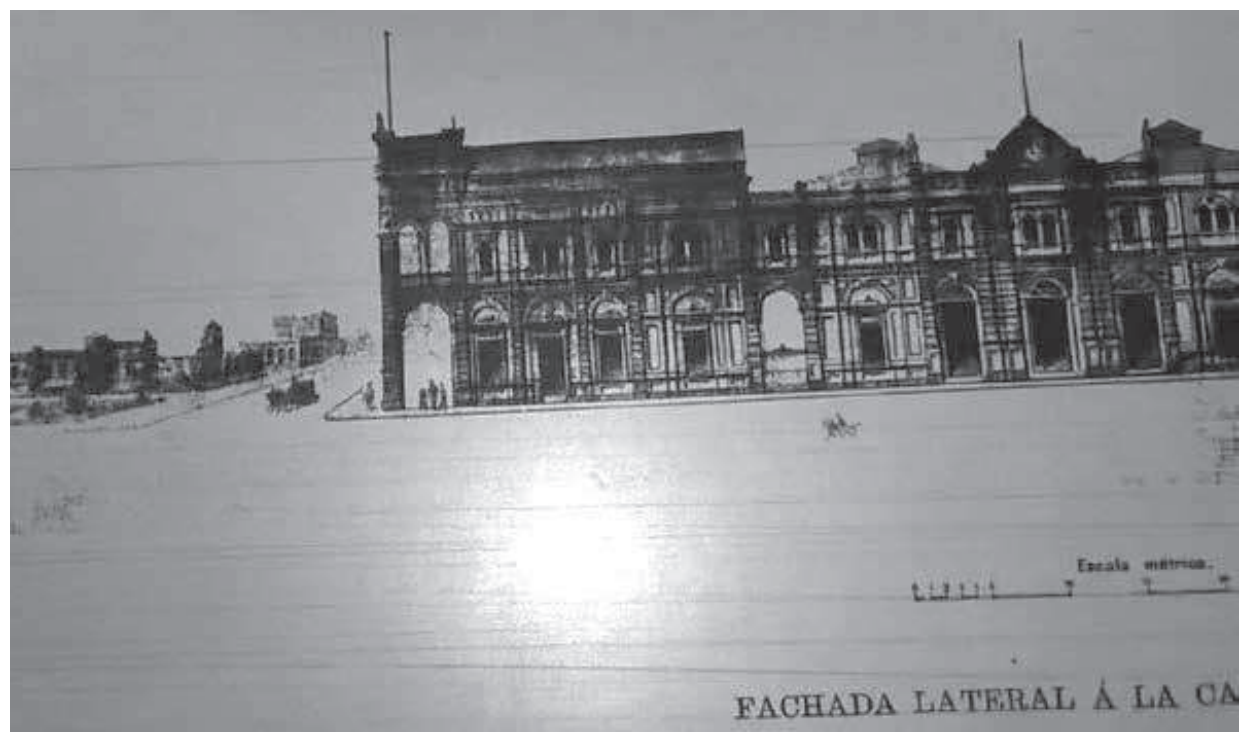

Sin embargo, las representaciones del espacio "deben ser entendidas como documentos que tienen una entidad compleja y que, en tanto objetosculturales, expresan los modos en que individuos e instituciones estatales y privadas perciben, experimentan y representan el mundo" (Dym, 2013, p. 11). Siguiendo la perspectiva de los estudios visuales en relación al paisaje, es imposible desligar estos documentos cartográficos de las intenciones y los modos de ver tanto de sus productores como de los actores que los hicieron circular, y los propios lectores y observadores ${ }^{9}$. Cuando los anuncios apelaban a los modos de representación técnicos lo hacían precisamente por esa experiencia del mundo que implicaban y por los intereses puestos en juegos desde las propias instituciones de la época.

En este sentido, las ilustraciones no responden completamente a la categoría de "paisaje" para sus contemporáneos: una "visión del espacio, luz y color", "los rastros característicos de la región”, "lo verdadero, la tranquilidad, el amor real y no ficticio" (Weschler, 1991). Sin embargo, si consideramos la representación del espacio de forma subjetiva, la proporción que toman las arquitecturas en relación a las figuras humanas y al entorno natural, y la inclusión de algunas escenas "de costumbres", podemos entender que participan de una visualidad ligada a ciertos intereses institucionales e ideológicos compartidos con las obras de paisaje canónicas que, ya en el siglo XX, definirán la dupla de "paisaje-identidad nacional”. Este sentido más profundo dela imagen surge aun cuando no sea consciente o programático.

9 Para más profundidad sobre la relación entre visualidad y geografía, ver el libro de Carla Lois y Verónica Hollman (2013) y el texto señero de Denis Cosgrove (2008). 
El carácter subjetivo del espacio construido por las ilustraciones no pasaba inadvertido para muchos contemporáneos; quienes, en contraposición, privilegiaban a la fotografía como precisa y verídica, cuyo estatuto técnico se oponía al artista. El estadista Francisco Latzina escribe en su Diccionario Geográfico Argentino:

\footnotetext{
Considerando las restricciones que nos imponían la índole de la obra, no quisimos sacrificar la severidad que la caracteriza al prurito de sorprender á sus lectores con los atractivos de una ilustración más ostentosa que adecuada. (...) Los cuadros que en una obra meramente literaria traza el genio del escritor los reproduce el lápiz del artista ó la máquina fotográfica en las obras científicas donde han de figurar, no como un elemento accesorio y de puro ornato, sino como datos complementarios y en algún sentido utilizables (1891, p. 799).
}

En este sentido, el estatuto de la fotografía como "dato", testimonio confiable, coloca a la imagen obtenida y reproducida mecánicamente a un nivel por lo menos similar al discurso textual, no como accesoria y, por lo tanto, prescindible. En el proyecto positivista de la elite gobernante en Buenos Aires por esos mismos años, este recurso en pos de una objetividad racional y científica no puede desvincularse de un relato moderno y un reclamo de contemporaneidad $^{\mathbf{1 0}}$.

Reclamo que, trayendo las palabras de Jonathan Crary, va ligado a aspectos económicos característicos del capitalismo industrial del siglo XIX: "La fotografía y el dinero se convierten en formas homólogas de poder social en el siglo XIX". Ambos discursos establecen cierto tipo de relación abstracta entre los individuos y las cosas, imponiendo su realidad como la única posible. Es de esta forma, sostiene Crary, que "todo un mundo social es representado y constituido exclusivamente como signos" (2008, p. 31).Algunos años más tarde, la fotografía y los cambios en los modos de ver y reproducir imágenes, gracias a adelantos en la impresión fotomecánica ${ }^{11}$, complejizarán los anuncios ilustrados. Por ejemplo, la imagen del reclame del Confortable Hotel de Mar del Plata, publicado en diciembre de 1899 en Caras y Caretas, utilizará un punto de vista bajo, una perspectiva menos forzada y juegos de luces y sombras en las fachadas del edificio que la vinculan con una toma fotográfica más que con un dibujo técnico. La fotografía (o un dibujo que apela en parte a sus modos de representación) dota a los anuncios de una "relación con lo real" que incluye el sistema económico, político e ideológico que lo hace posible.

10 Remito aquí al reciente y altamente recomendable libro de Verónica Tell sobre el estatuto de las fotografías a fines del siglo XIX (2017).

11 Sobre los cambios en las técnicas de impresión y el "contexto técnico-industrial de la cultura tipográfica”, léase el texto de Sandra Szir (2014) 
Figura 12. Anuncio de “Confortable Hotel”. Caras y Caretas, $n^{\circ}$ 65, 30 de diciembre de 1899

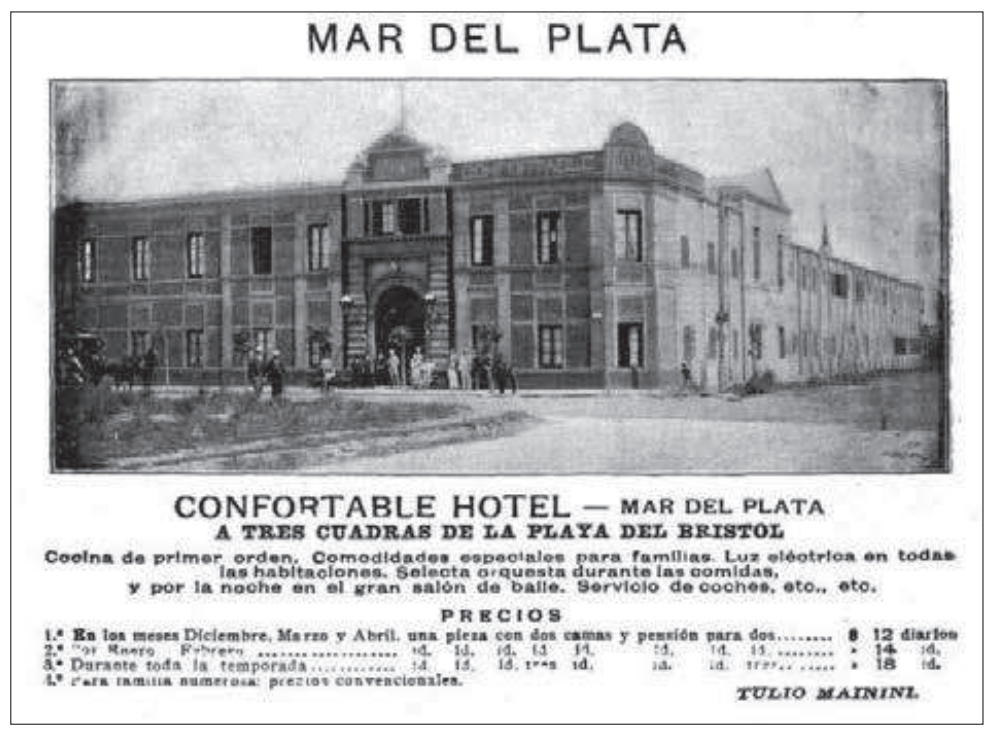

Otro caso interesante donde se conjugan fotografía, publicidad y arquitectura es en El Sud-Americano. Este periódico ilustrado que aparece por primera vez en 1888, editado por la Compañía Sudamericana de Billetes de Banco, ordenaba sus anuncios de forma tradicional en páginas específicamente dispuestas para ello al principio y al final de cada número. Esta característica propia de las revistas (y no tanto de los diarios que mantenían aún la preponderancia de los avisos tipográficos ordenados por rubro) permitía al lector y suscriptor transformarse en coleccionista, quitando esas páginas y encuadernando los tomos completos, con lo que obtenía una especie de álbum con secciones literarias, artísticas o de novedades ${ }^{12}$.

En la sección de avisos de El Sud-Americano podemos encontrar una distribución original de los mismos. Los diferentes reclames, con poca o ninguna ilustración, se encuentran rodeando un grabado de un paisaje de Buenos Aires. Enla Plaza de Mayo con la Pirámideyla Catedral en primer plano, ylos edificios monumentalizados por detrás, "las construcciones arquitectónicas dominan el entorno, la realidad material de las instituciones está por sobre el nivel de los individuos" (Szir, 2013, p. 6) vinculando la página comercial con el estilo de las ilustraciones de sucesos o interés del cuerpo del periódico.

12 Para un análisis de las ilustraciones del periódico, léase el artículo de Sandra Szir (2013). 
Figura 13. Sección de avisos. El Sud-Americano, 5 de febrero de 1890

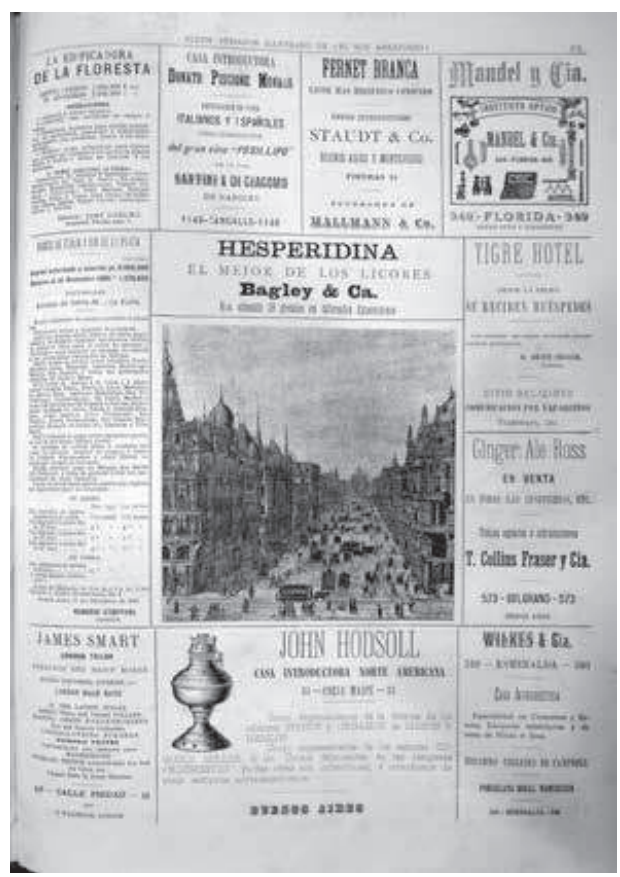

Figura 14. El Sud-Americano, 20 de diciembre de1889

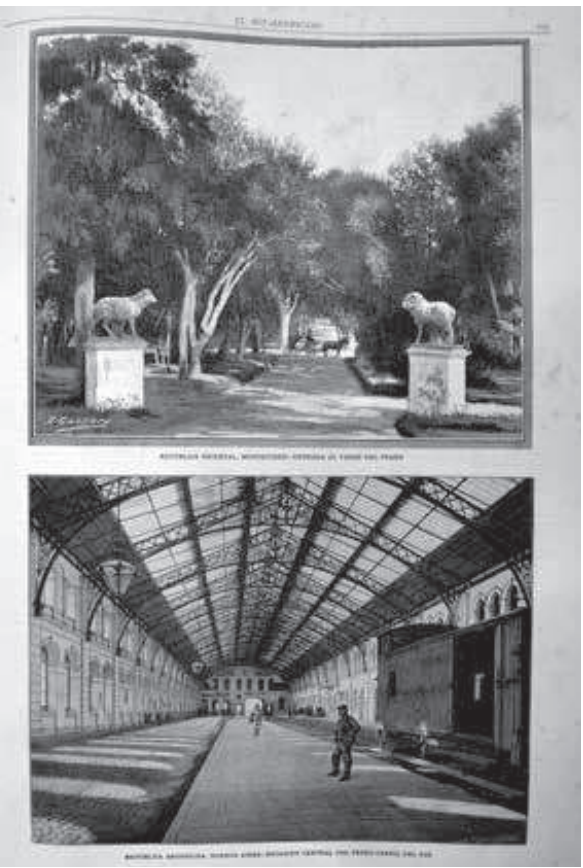

Entre las notas solían aparecer ilustraciones de paisajes o edificios, firmadas por los dibujantes. La yuxtaposición de estas ilustraciones en las páginas generaba discursos alternativos y sumamente interesantes, como la vista del Paseo del Prado en Montevideo con el interior de la estación Constitución del Ferrocarril del Sud.

La primera imagen, firmada por A. Gaspary ${ }^{\mathbf{1 3}}$, presenta la entrada al Paseo y el tratamiento de los árboles, los juegos de luces y sombras, y el punto de vista adoptado remite igualmente a una toma fotográfica. En el segundo caso la vinculación es más exacta, ya que podemos encontrar la toma en que se pudo haber basado el artista: una fotografía tomada por la casa Witcomb, perteneciente al Archivo General de la Nación. El vagón de carga y el guarda pueden ser adaptaciones del artista o remitir a una fotografía de la misma serie que no perduró en el archivo. Lo que sí puede observarse, comparando ambas imágenes, es que se trata de un punto de vista similar, que privilegia en este caso un horizonte medio y donde podría situarse un observador cualquiera.

13 Este dibujante podría haber participado también en la Estadística Gráfica de 1892; aun cuando en esas láminas la firma pareciera decir R. Gaspary, la caligrafía y el estilo de las ilustraciones son similares. 
Figura 15. Casa Witcomb, Estación del Ferrocarril del Sud en la Plaza Constitución. Archivo General de la Nación, Inv. 506

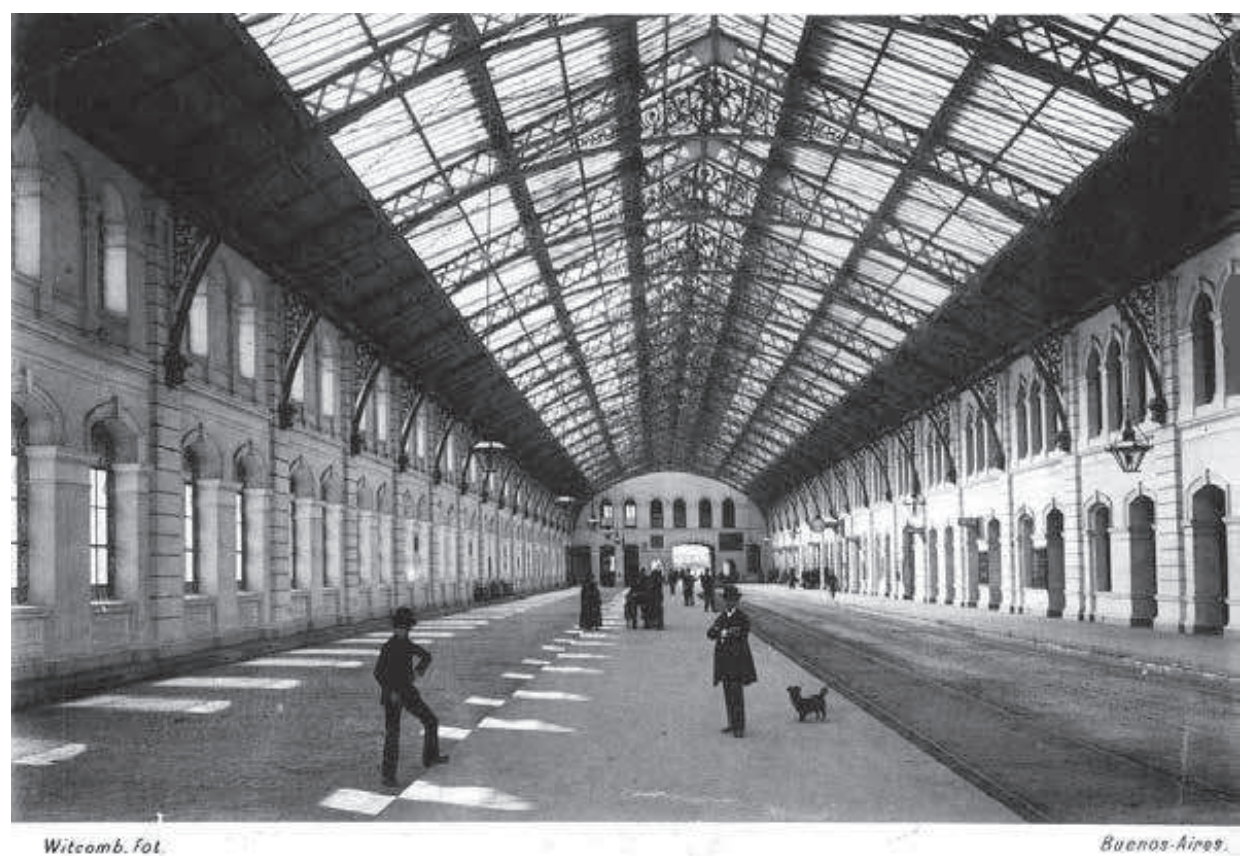

La imagen fotográfica es reconocible por cualquier usuario del ferrocarril. Los personajes retratados brindan cierto aire de espontaneidad al mirar a la cámara, aunque los tiempos de exposición no eran los actuales. Pero también hay, suspendida en ese amplio espacio de líneas que se cortan formando una textura de hierro y vidrio, una sensación de lo inminente, del vértigo del ferrocarril que debe estar por llegar pero que no llega, que permite que el fotógrafo realice esta toma justo en este momento. Los personajes que miran la cámara también miran el tren o hacia donde debería estar el tren. Cámara y locomotora se yuxtaponen, ambas como símbolos del progreso, de la modernidad, de la velocidad y de la necesidad de fijar ese tiempo, yla posibilidad de manipular el espacio, de orden y de caos (Charney \&Schwartz, 1995). Símbolos en fin de una percepción completamente nueva de la ciudad, que responde más a intereses en pugna y "fisuras del tiempo y el espacio quebrados de la metrópolis moderna" (Gorelik, 1998, p. 11).

En el grabado cambian algunos detalles, los suficientes para hacer más amigablela imagen. Elcambio en la posición delartista, ligeramentehacialaizquierda, le permite retratar de diferente forma a los personajes, y dar lugar al vagón de madera que pasa por la derecha del andén. Le permite modificar los juegos de luces y sombras, y cortar de esta forma esa textura casi infinita que construye la fotografía, como los juegos ópticos característicos también de la modernidad. La huella del artista se hace más visible, y la sensación de vértigo desaparece. 
Este ejemplo es también interesante, ya que está firmado por Brend'amour, quien podría ser Richard Brend’amour, xilógrafo alemán que vivió entre 1831 y 1915 y que fundó un taller en Dusseldorf, famoso por sus reproducciones fotomecánicas. La misma ilustración está reproducida en la revista The Arrow de la comunidad británica en Buenos Aires. Esto generó una red mucho más compleja de circulación de imágenes, actores e intereses más allá de la circulación material de los objetos gráficos, circulación que se vincularía también con el ferrocarril de diferentes maneras.

Figura 16. The Arrow, 1893

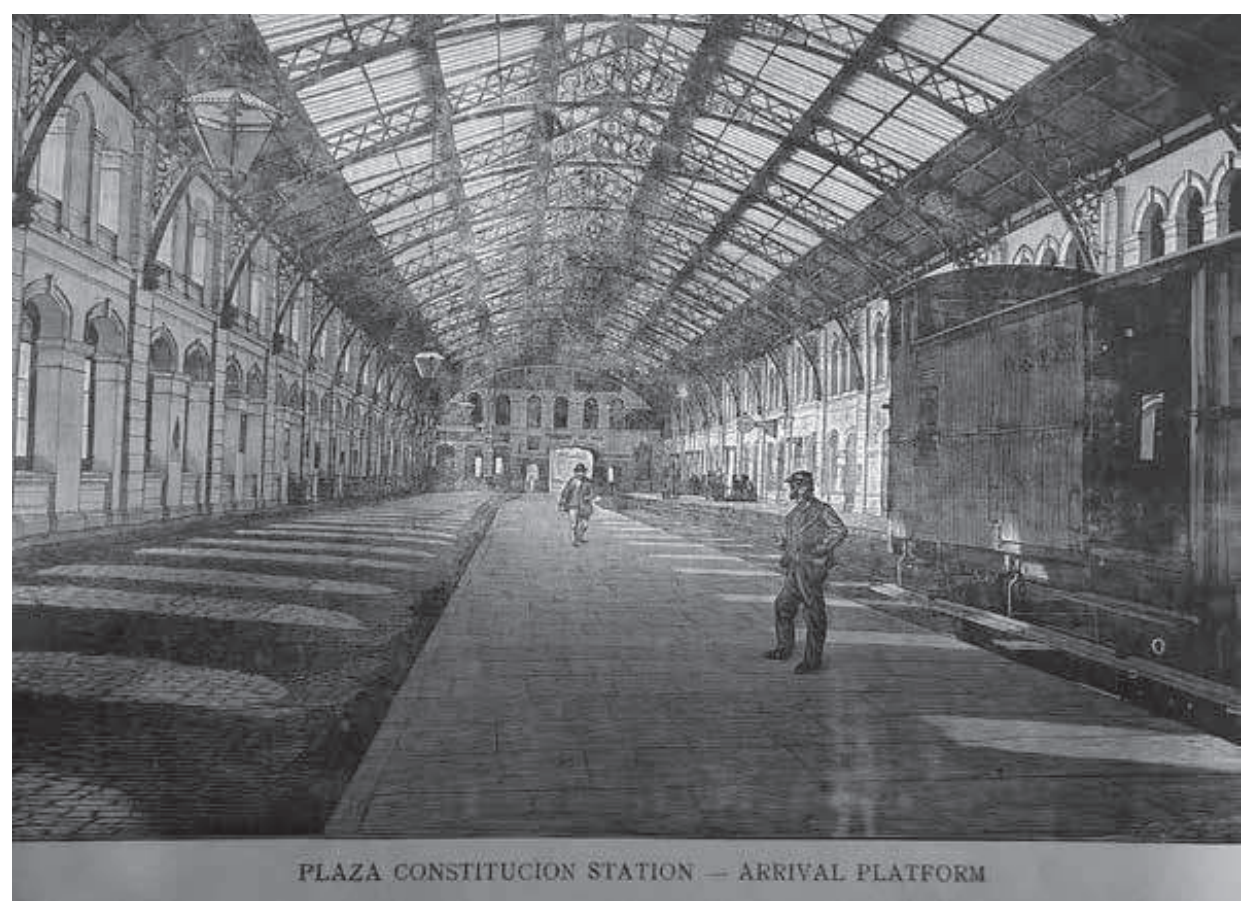

\section{EL FERROCARRIL}

La representación del paisaje urbanoyrural severáfuertementecondicionada en esta época por el ferrocarril, que implicó cambios en la percepción del espacioy el tiempo, por su desarrollo técnico y simbólico en el imaginario moderno. Ya en su libro de los Pasajes, Benjamin establece una vinculación decisiva entre el tren y las grandes construcciones a partir del material estrella de la ciudad moderna:

Por primera vez en la historia de la arquitectura, un material de construcción artificial aparece: el hierro. Ésta sufre una evolución cuyo ritmo se acelerará en el transcurso del siglo. Este desarrollo entra en una nueva fase decisiva cuando se vuelve patente que la locomotora -en la que se realizan experimentos desde finales de la década de 1820 - sólo es compatible con vías de hierro. El riel es el primercomponente dehierro prefabricado, precursor dela viga. El hierro se evita enla construcción doméstica, pero es usada en las arcadas, en salas de exposición, estaciones de trenes -edificios que sirven para fines transitorios (2013, p. 4). 
La misma descripción que Deleuze realiza del dispositivo de Foucault citada al comienzo de este trabajo se basa en esta experiencia de un camino que atraviesa el mapa como una locomotora, líneas que componen y cruzan el espacio, "máquinas para hacer ver y para hacer hablar" (1999, p. 155). Lo geográfico, racionalizado y ordenado visual y corporalmente a partir de las vías del ferrocarril, es metáfora de la experiencia. La máquina es el dispositivo que lo atraviesa, le da múltiples sentidos, lo humaniza y a la vez lo objetiviza. Visibilidad y enunciación, imagen y texto, experiencia y racionalidad. Pero también irracionalidad, caos, azar y peligro. El ferrocarril es, para sus contemporáneos, representación última del progreso científico y tecnológico, del dominio del hombre sobre el territorio (y por eso jugó un papel relevante en la consolidación de los límites luego del paso del ejército en la Campaña del Desierto (Míguez, 2015). Por otro lado, es la posibilidad del caos constante y la materialización de los peores temores, por lo que abundan las noticias de accidentes, de abandono de vías, de negocios fallidos ${ }^{14}$.

Figura 17. La catástrofe de Castel Giubileo. Caras y Caretas, $n^{\circ} 102$, 15 de septiembre de 1900

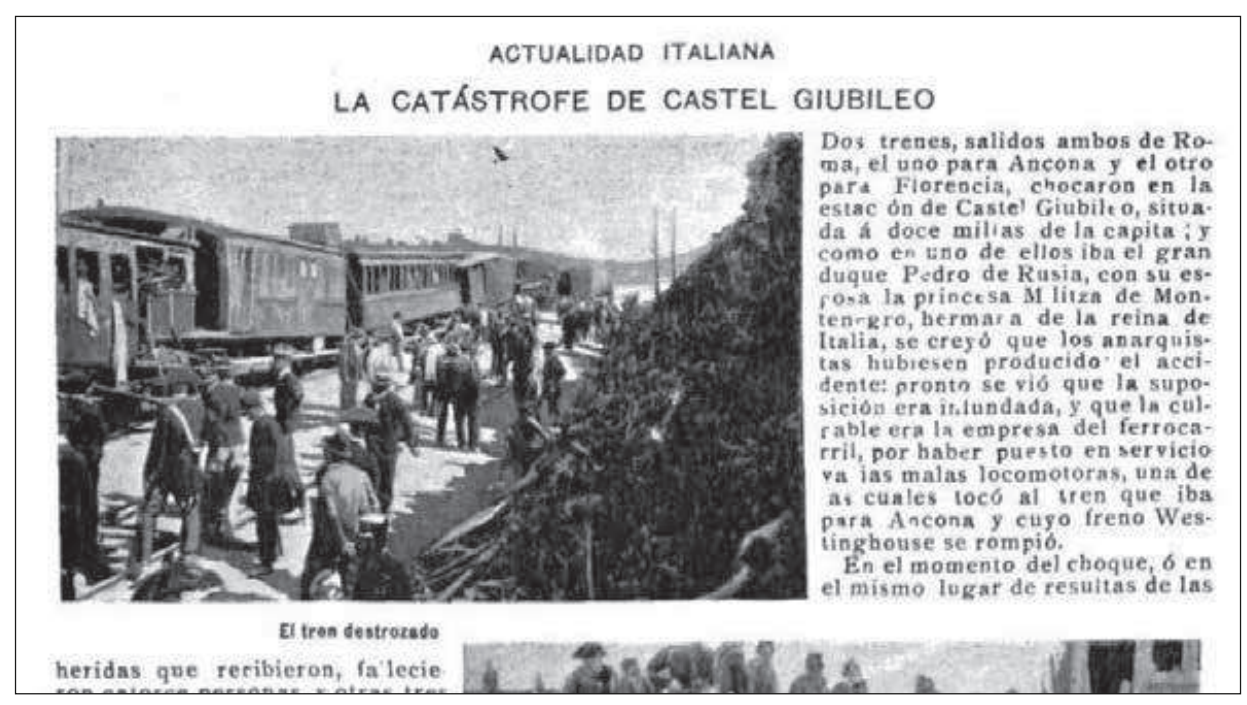

En cuanto al espacio urbano, el ferrocarril lo cruza y al mismo tiempo lo delimita. Las estaciones centrales marcan la diferencia con las intermedias, por su imponencia e incluso por su vinculación con las vías y andenes. La planificación del tendido ferroviario estuvo condicionada desde un primer momento por el modelo agroexportador, vinculando los sectores productivos (el otrora "desierto") con el puerto, y desde allí con el resto del mundo.

La ubicación de las estaciones modificaba el entorno, pero no sólo en un nivel económico (movimiento de mercancías y pasajeros), sino, y particularmen-

14 Léase el capítulo sobre la representación de los ferrocarriles de Peter Sinnema (1998), así como el texto de Ben Singer (1995) sobre el hiperestímulo y el sensacionalismo en la prensa ilustrada británica. 
te, sociocultural, porque se convertían en puntos de encuentro, de contacto y de fomento de nuevas prácticas comunitarias. El trazado ferroviario impulsaba de esta forma núcleos urbanos, más allá de las intenciones de sus ideólogos. Es lo que los contemporáneos mismos describían como "urbanización de la locomotora”. En América Latina, a la inversa de lo que ocurría en el "viejo continente", el ferrocarril no atraviesa y transforma ciudades ya establecidas, sino que son sus nodos de intercambio, los "puntos de ruptura" los que generan nuevos espacios urbanos, y tuvieron "un efecto poblador casi comparable al generado por la conquista siglos atrás” (Tartarini, 2000, p. 38).

Esta modificación de la vida social, más allá de lo puramente económico, se hace patente no sólo en Buenos Aires, con la adaptación de los ferrocarriles al transporte de pasajeros. El turismo, si bien no se puede decir que fuera originado por el desarrollo ferroviario, sí fue impulsado a un nivel inimaginado en el Londres victoriano, al hacer posibles los viajes a largas distancias, de grandes grupos familiares, entre ciudades que encontraron de esta forma una alternativa a la gran urbe industrial (Simmons, 1984). Es por ello que muchos de los edificios de las grandes tiendas o los hoteles serán propiedad de las mismas compañías ferroviarias, que impulsaron a su vezlas artes gráficas con el objetivo de publicitar de forma más atractiva los nuevos destinos ${ }^{15}$.

Como describe Simmons (1984), estas compañías comenzarán a ampliar su marco de negocios e incluir actividades supuestamente complementarias, lo que será fuertemente criticado en un primer momento para, ya en los últimos años del siglo XIX, cuando establezcan sucursales en América Latina, ser la moneda corriente e incluso una práctica fomentada desde los ámbitos políticos.

Si bien en el Río de la Plata estas estrategias se implementaron en las primeras décadas del siglo XX, con la publicación de revistas, guías turísticas, afiches, mapas, entre otros objetosimpresos, la vinculación entrelas compañías ferroviarias (en particular las de capitales británicos) y las tiendas y hoteles fue una constante en la última década del siglo XIX; la instalación del balneario en la ciudad de Mar del Plata es un ejemplo paradigmático.

Por otro lado, el ferrocarril implicaba espacios y prácticas de lectura nuevos, muchas veces sociales. Los reclames y afiches colocados en sus paredes, los mapas, gráficos, horarios y tarifas implicaban una capacidad de comprensión que no siempre existía. Se necesitaban "mediadores" que socializaran los textos de forma oral similar a otras instancias como el teatro o el circo. Las ilustraciones en los reclames o las pequeñas viñetas en los dispositivos impresos por las mismas compañías servían también muchas veces de ordenadores visuales del discurso y mediadores ante un público heterogéneo.

15 En el caso de los ferrocarriles londinenses, es sumamente interesante el artículo de John Hewitt (2000) sobre la relación entre las elites económicas y políticas y el campo artístico canónico. 
Figura 18. Casa Vargas Machuca, Tipos populares, vendedor de diarios. Archivo General de la Nación, Inv. 169230

En este sentido, es interesante observar que las propias compañías británicas fueron integrando una compleja red entre imprentas y editoriales, por lo cual los diferentes objetos compartían autores, editores, ilustradores, técnicos e incluso un mismo espacio de trabajo. Estas relaciones se cruzan en la visualidad de estos objetos, en las ilustraciones reiteradas, en los tipos y clichés utilizados, en el formato del papel y las tintas, etc. Características que, a su vez, eran compartidas por los periódicos, los grandes afiches, los boletines y la miscelánea producida por las compañías.

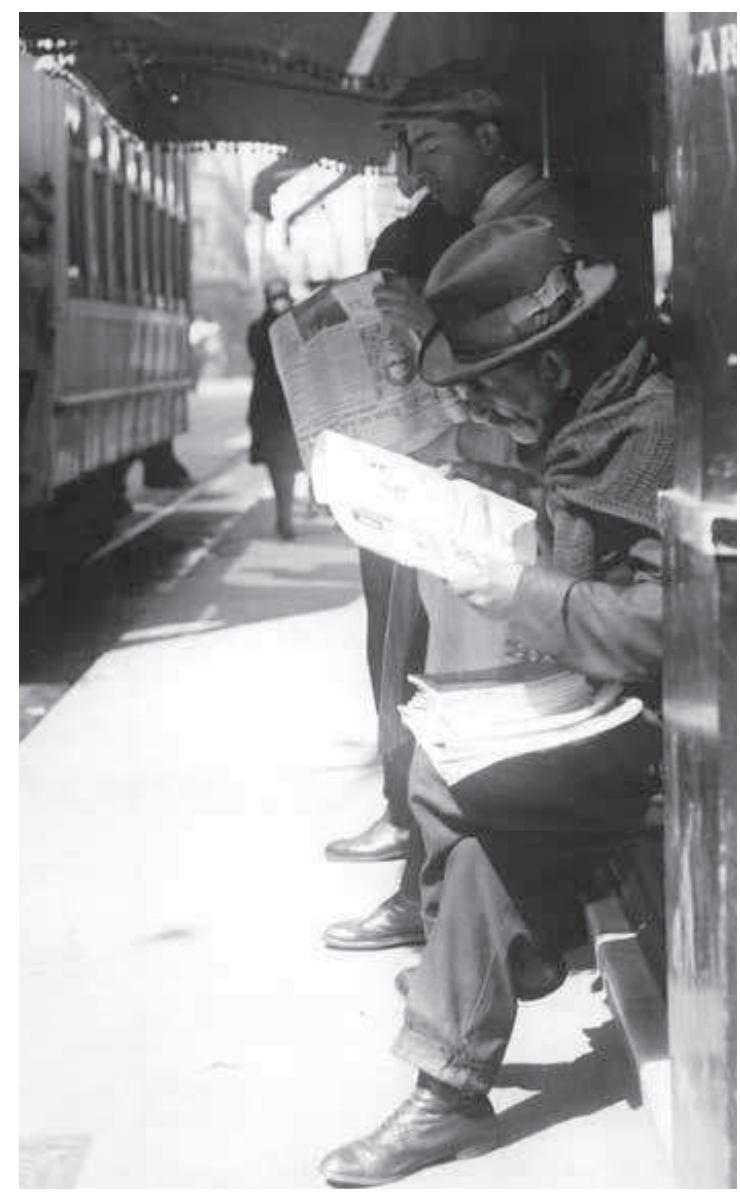

Figura 19. Desarrollo de la Estación Terminal Plaza Constitución, Archivo General de la Nación, Inv. 45673

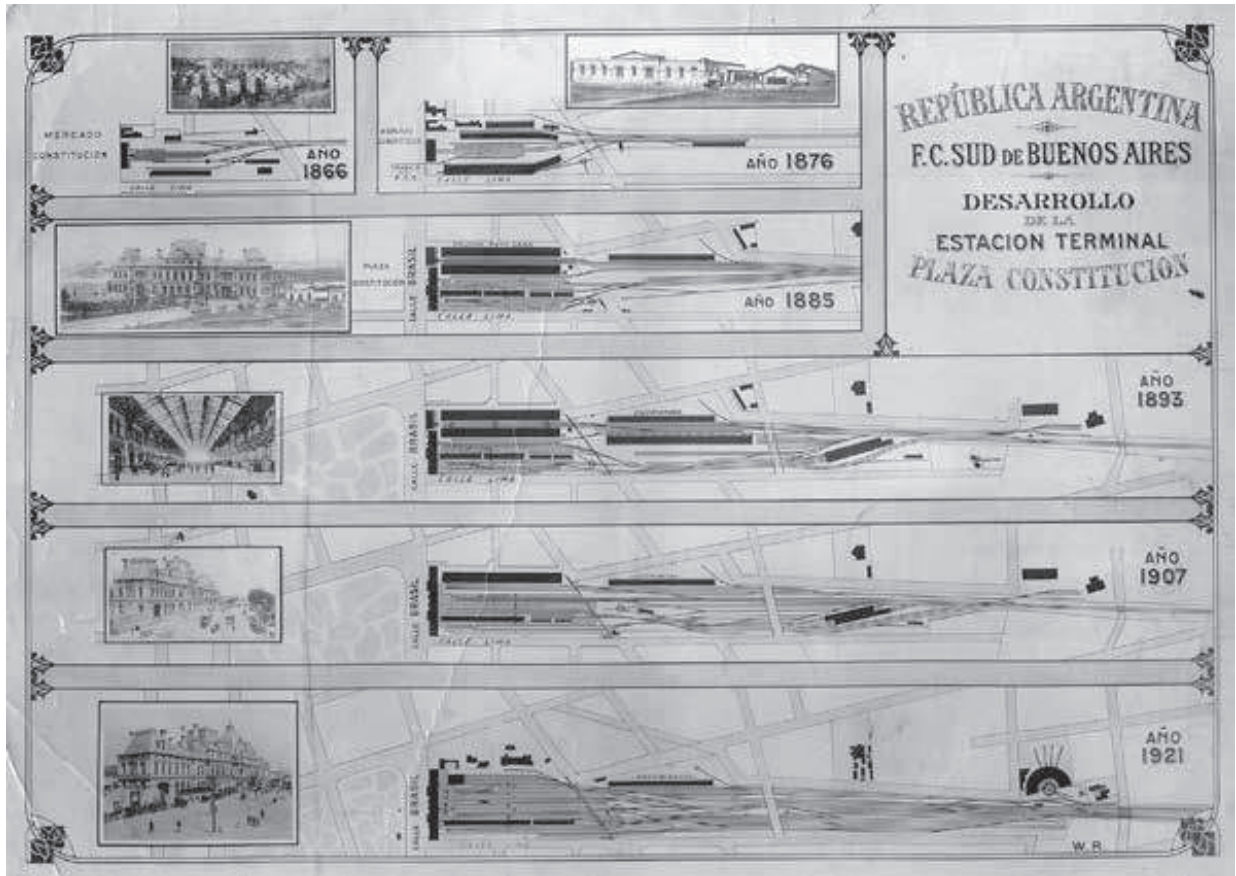


Además de la vinculación con el turismo, las compañías ferroviarias, los almacenes e industrias produjeron una cantidad importante de boletines, gráficos y miscelánea relacionada con las actividades comerciales. Hacia el final del siglo XIX la necesidad de profesionales especializados en el diseño y la propaganda influirá en la creación de departamentos específicos. En 1900 el norteamericano David Austin tomará el cargo por primera vez de Purchasing Agent del Buenos Aires Western Railway (Ferrocarril Oeste), en una época temprana considerando la descripción de Simmons del panorama internacional:

Los ferrocarriles hicieron poco para publicitarse, excepto en folletos muy simples y en avisos insertos en la prensa sobre nuevas o mejoradas instalaciones, hasta los últimos años del siglo XIX. Entonces ellos comenzaron (bajo la influencia norteamericana) a apreciar el valor de la publicidad en términos amplios. (...) El estándar general de la publicidad ferroviaria era bajo, y muchas veces eran criticados por el horrible caos de los reclames que se permitían en las estaciones. Pocas compañías, reconociendo que la empresa requería de experiencia, organizaron sus propios departamentos de publicidad (1984, p. 210).

Diez años más tarde Austin se convertirá en el agente de propaganda de los Ferrocarriles Británicos (Damus, 2011) y controlará la imagen de las compañías más poderosas.

\section{CAMBIO DEÉPOCA}

Durante las primeras décadas del siglo XX las campañas publicitarias se alejarán paulatinamente de la identificación del producto con un espacio determinado (almacenes, tiendas, mercados), respondiendo a nuevas dinámicas de producción y comercio, pautas de consumo diferentes, asícomo prácticas de lectura y códigos visuales específicos de la disciplina. Las condiciones técnicas de posibilidad de las imágenes impresas también modificarán estas pautas. En este sentido, es insoslayable el rol del magazine Caras y Caretas, publicado desde 1898, en la consolidación de un estatus de la ilustración en la prensa y de la tecnología en el campo de las artes gráficas ${ }^{\mathbf{1 6}}$.

Mediante el análisis de estas tempranas imágenes publicitarias, a partir de sus características específicas de producción y circulación, insertas en medios gráficos heterogéneos, se propuso dar cuenta de diferentes tensiones existentes en el momento, tales como la heterogeneidad de códigos visuales en la representación del espacio arquitectónico; la vinculación de la imagen impresa con ámbitos y circuitos de consumo extra-artísticos, como publicaciones ferroviarias, financieras, guías comerciales, técnicas, manuales, estadísticas, etc.; la consolidación de imágenes identitarias del consumo urbano a partir de su representación arquitectónica y su inserción en el entorno. 
Para comprender el pasado es necesario preguntarse sobre la evolución de la tecnología y su relación con la sociedad y la cultura (Kranzberg, 1959). Al vincular los aspectos comerciales, políticos y técnicos con la cultura visual se intentó abrir nuevas puertas a la comprensión de la cultura visual en una época marcada por la rapidez de los cambios y la fluidez en las prácticas disciplinares que se estaban conformando. Al analizar las diferentes imágenes insertadas en los dispositivos gráficos resulta necesario ampliar estos cruces, ya que las condiciones materiales de producción y circulación complejizan y enriquecen el análisis.

Desdela perspectiva de los estudios culturales, la "modernidad", como "expresión de los cambios en la llamada experiencia subjetiva", ha sido vinculada a unas pocas "innovaciones talismánicas" (Charney \& Schwartz, 1995, p. 1), particularmente la locomotora a vapor. A su vez, el ferrocarril como máquina y medio de transporte estuvo inmerso en las grandes transformaciones sociales, económicas y culturales en las que la circulación de discursos, sujetos y objetos jugó un rol relevante, modificando la percepción de categorías hasta ese entonces permanentes. Los grandes cambios urbanísticos estuvieron vinculados a esta metáfora a través del acceso al consumo de objetos, información y modas, dentro del contexto de construcción de una identidad nacional en el quela gráfica jugó un papel fundamental, a partir dela circulación de discursos, emblemas y paisajes nacionales.

Es por ello que analizar estas imágenes como dispositivos complejos, vinculadas a sus desarrollos técnicos y al contexto social, económico y político, permitirá comprender cómo funcionó y en qué medida se fue conformando la cultura visual de Buenos Aires en una época bisagra, cuyas decisiones en materia urbana continúan configurando hoy en día nuestros propios rituales.

\section{REFERENCIAS}

Amigo, R. (2013). Carlos Morel. El costumbrismo federal. En Caiana. Revista de Historia delArte y Cultura Visual del Centro Argentino de Investigadores de Arte(CAIA), (3). Recuperado: 30/10/2017. En línea: http://caiana.caia.org.ar

Benjamin, W. (2003). The arcades project. Cambridge, MA: The Belknap Press of Harvard University Press.

Bonaudo, M. (Ed.). (1999). Nueva Historia Argentina: Liberalismo, Estado y Orden Burgués (1852-1880). Vol. 4. Buenos Aires: Sudamericana.

BonelliZapata, A. (2016). “Fachadas en venta. Imágenes impresas estadística y geografía en la Exposición de Chicago de 1893”. En Sandra Szir (editora), Ilustrar eimprimir. Una historia de la cultura gráfica en Buenos Aires, 1830-1930(pp. 113-143). Buenos Aires: Ampersand. 
Bourdé, G. (1977). Buenos Aires: Urbanización e Inmigración. Buenos Aires: Huemul.

Bruno, P. (2012).Los hoteles de turismo (1930-1955): piezas claves del territorio turístico de la Argentina. En Registros, (9), 54-80. Recuperado: 30/10/2017). En línea: https://revistasfaud.mdp.edu.ar/registros/article/view/84

Camacho, H. (s/f). Institucional. Presidente Eduardo Aguirre. En Academia Nacional de Ciencias Exactas, Físicas y Naturales. Recuperado: 30/10/2017. En línea: http:// www.ancefn.org.ar/institucional/aguirre.html

Charney, L. \& Schwartz, V. (eds.) (1995). Cinema and the Invention of Modern life. Berkeley, California: University of California Press.

Cosgrove, D. (2008). Geography and vision: Seeing, imagining and representing the world. New York: I.B. Tauris.

Crary, J. (2008). Las técnicas del observador: Visión y modernidad en el siglo XIX. Ad literam. Murcia: CENDEAC.

Damus, S. (2011). Who was who in Argentine Railways (1860-1960). Ontario, Canadá: DIA Agency.

De Certeau, M. (1990). La invention du quotidien. Paris: Flammarion.

Deleuze, G. (1999). ¿Qué es un dispositivo?. En G. Deleuze y É. Balibar (Eds.), Michel Foucault, filósofo (pp. 155-163). Barcelona: Gedisa.

Didi-Huberman, G. (2008). Ante el tiempo: Historia del arte y anacronismo de las imágenes. Buenos Aires: Adriana Hidalgo.

Dym, J. (2013). Prefacio. En Carla Lois y Verónica Hollman. Geografía y Cultura Visual. Los usos de las imágenes en las reflexiones sobre el espacio (pp. 11-14). Rosario: Ediciones Prohistoria-Universidad Nacional de Rosario.

Fara, C. (2016). Recorridos de la modernidad. Arte y cultura visualen las representaciones del paisaje urbano de Buenos Aires entre 1910 y 1936. Tesis doctoral de la Facultad de Filosofía y Letras, Universidad de Buenos Aires (UBA), Argentina (mimeo).

Félix-Didier, P. y Szir, S. (2004). Ilustrando el consumo. Mundo Clásico. Recuperado: 04/12/2017. En línea: http://www.mundoclasico.com/ed3/documentos/5775/ Ilustrando-consumo

Gilbert,J.(2013).Ernesto Tornquist, entrelosnegociosylas políticaseconómicas. Revista de Instituciones, Ideas y Mercados, (58), 47-78. Recuperado: 30/10/2017. En línea: http://www.eseade.edu.ar/wp- content/uploads/2016/08/riim58_gilbert.pdf

Goldgel, V. (2013). Cuando lo nuevo conquistó América: Prensa, moda y literatura en el siglo XIX. Metamorfosis. Buenos Aires: Siglo Veintiuno Editores.

Gorelik, A. (1998). La grilla y el parque. Espacio público y cultura urbana en Buenos Aires, 1887-1936. Buenos Aires: Universidad Nacional de Quilmes. 
Gunning, T. (1995). Tracing the individual body: Photography, Detectives, and Early Cinema. En Leo Charney y Vanessa Schwartz (Eds.). Cinema and the Invention of Modern life. Berkeley, California: University of California Press.

Hewitt, J. (2000). Posters of Distinction: Art, Advertising and the London, Midland, and Scottish Railways. Design Issues, 16(1). Recuperado: 13/4/2017. En línea: https:// doi.org/10.1162/074793600300159574

Kranzberg, M. (1959). Al comenzar. Technology and culture, 1(1).

Latzina, Francisco (1891). Diccionario Geográfico Argentino. Buenos Aires: Ramón Espasa y Cía. Editores.

Liernur, J. F. (2000). La construcción del país urbano. En Mirta Zaida Lobato (Dir.). Nueva Historia Argentina: El progreso, la modernización y sus límites (1880-1916) (pp. 409-463). Buenos Aires: Sudamericana.

Lobato, M. (Dir.). (2000) Nueva Historia Argentina: El progreso, la modernización y sus límites (1880-1916). Buenos Aires: Sudamericana.

Lobato, M. (2001). La vida en las fábricas: Trabajo, protesta y política en una comunidad obrera, Berisso (1904-1970). Buenos Aires: Prometeo Libros.

Majluf, N. (2006). Pattern-book of Nations: Images of Types and Costumes in Asia and Latin America, 1800-1860. En Reproducing Nations: Types and Costumes in Asia and Latin America, ca. 1800-1860 (catálogo). New York: Americas Society.

Malosetti Costa, L. (s/f). La Vuelta del Malón, Ángel Della Valle. En Museo Nacional de Bellas Artes. Recuperado: 30/10/2017. En línea: https://www.bellasartes.gob.ar/ coleccion/obra/6297

MalosettiCosta, L. \& Gené, M. (editoras). (2009). Impresiones Porteñas: Imagen y palabra en la historia cultural de Buenos Aires. Buenos Aires: Edhasa.

Míguez, E. (2015). Poblando la frontera. El sur y oeste bonaerense 1880-1914. Forjando, 4.

Rocchi, F. (1998). Consumir es un placer: La industria y la expansión de la demanda en Buenos Aires a la vuelta del siglo pasado. En Desarrollo Económico, 37(148), 533-558.

Rogind, W. (1937). Historia del Ferrocarril Sud. Buenos Aires: Establecimiento Gráfico Argentino.

Román, C. (2017). Prensa, política y cultura visual. El Mosquito (Buenos Aires 18631893). Buenos Aires: Ampersand. 
Samson, J. (1904). Buenos Aires, impresiones de un viajero. En Revista Técnica, suplemento de Arquitectura 1(1). Recuperado: 30/10/2017. En línea: http:// biblioteca.fadu.uba.ar/tiki-index.php?page=revista_tecnica_I

Scobie, J. (1974). Buenos Aires. Plaza to Suburb, 1870-1910. New York: Oxford University Press.

Silva, A. (2006). Imaginarios Urbanos. Bogotá: Arango Editores.

Simmons, J. (1984). Railway, Hotels, and Tourism in Great Britain 1839-1914. In Journal of Contemporary History, 19(2), 201-222.

Singer, B. (1995). Modernity, Hyperstimulous and the rise of the popular sensationalism. In Leo Charney y Vanessa Schwartz (Eds.), Cinema and the Invention of Modern life. Berkeley, California: University of California Press.

Sinnema, P. (1998). Dynamics of the Pictured Page: Representing the Nation in the Illustrated London News. Aldershot, England: Ashgate.

Szir, S. (2009). Dela cultura impresa a la cultura delo visible. Las publicaciones periódicas ilustradas en Buenos Aires en el siglo XIX. Colección Biblioteca Nacional. En Garabedian, Marcelo, Szir, Sandra y Lida, Miranda (editoras), Prensa argentina siglo XIX. Imágenes, textos y contextos. Buenos Aires: Ediciones Biblioteca Nacional/Teseo.

Szir, S. (2010). Figuraciones urbanas. Caras y Caretas, 1900. En Dinámica de una ciudad. Buenos Aires, 1810-2010. Buenos Aires: Dirección General deEstadísticayCensos. Gobierno de la Ciudad de Buenos Aires.

Szir, S. (2013). Reporte documental, régimen visual y fotoperiodismo. La ilustración de noticias en la prensa periódica de Buenos Aires (1850-1910). Caiana. Revista de Historia del Arte y Cultura Visual del Centro Argentino de Investigadores de Arte (CAIA), (3). Recuperado: 30/10/2017. En línea: http://caiana.caia.org.ar

Szir, S. (2014). Arte, tecnología y prácticas gráficas en la historia material de los periódicos ilustrados. Buenos Aires (1860-1920). Anuario Tarea, (1), 99- 116. Recuperado: 30/10/2017. En línea: de http://www.unsam.edu.ar/ revistasacademicas/index.php/tarea/issue/viewIssue/8/

Tartarini, J. (2000). Arquitectura ferroviaria. Buenos Aires: Ediciones Colihue.

Tell, V. (2017). El lado visible: Fotografía y progreso en la Argentina a fines del siglo XIX. San Martín: UNSAM Edita.

Wechsler, D. (1991). Paisaje, crítica e ideología. En Ciudad-campo en las artes en Argentina y Latinoamérica. Buenos Aires: Centro Argentino de Investigadores de Arte, 1991. 


\section{HEMEROGRAFÍA}

Álbum Ilustrado dela República Argentina, № 1, 15/07/1891.Editores Müllery Johnson. Hemeroteca Biblioteca Nacional Mariano Moreno, Buenos Aires, Argentina.

Caras y Caretas, No 65, 30/12/1899. Biblioteca Nacional de España. Recuperado: 30/10/2017. En línea: http://hemerotecadigital.bne.es/

Caras y Caretas, № 102, 15/09/1900. Biblioteca Nacional de España. Recuperado: 30/10/2017. En línea: http://hemerotecadigital.bne.es/

El Ingeniero Civil, año 1,n³ 3,01/05/1888. Editor Guillermo Kraft. Hemeroteca Biblioteca Nacional Mariano Moreno, Buenos Aires, Argentina.

El Sud-Americano, Año 1889. Compañía Sudamericana de Billetes de Banco. Biblioteca Ernesto Tornquist, Banco Central de la República Argentina.

Estadística Gráfica. Progreso de la República Argentina en la Exposición de Chicago, Empresa de la Patria Ilustrada, Año 1892. Biblioteca Ernesto Tornquist, Banco Central de la República Argentina.

Revista Técnica, suplemento de Arquitectura, No 1, abril 1904. Biblioteca Facultad de Arquitectura, Diseño y Urbanismo, Universidad de Buenos Aires, Argentina. Recuperado: 30/10/2017. En línea: http://biblioteca.fadu.uba.ar/tiki-index. php?page=revista_tecnica_I

The Arrow, The monthlyillustrated magazine of the River Plate, Año 1893. Editor A. Stuart Pennington. Biblioteca Max von Buch, Universidad de San Andrés.

The Financial Review of the River Plate, No 2, 19/12/1891. Biblioteca Ernesto Tornquist, Banco Central de la República Argentina.

TheStandard, Año 1891.Editores Michael George \&Edward Thomas Mulhall. Biblioteca Max von Buch, Universidad de San Andrés.

\section{IDENTIFICACIOON DE LAAUTORA}

Ana Bonelli Zapata es Licenciada en Artes (Orientación Artes Plásticas) por la Facultad de Filosofía y Letras, Universidad de Buenos Aires (UBA), Argentina. Doctoranda en Historia por el Instituto de Altos Estudios Sociales (IDAES), Universidad Nacional de San Martín (UNSAM), Argentina. Ha participado y participa en proyectos de investigación relacionados con las artes gráficas y cultura visual. Su investigación gira en torno a la vinculación entre las artes gráficas y el desarrollo ferroviario en el Río de la Plata (1890-1930).

\section{REGISTRO BIBLIOGRÁFICO}

Bonelli Zapata, A. (2017). Imagen impresa y ciudad, Buenos Aires (1890-1910). InMediaciones de la Comunicación, 12(2), 99-127. 